\title{
Properties of aerosols and formation mechanisms over southern China during the monsoon season
}

\author{
Weihua Chen ${ }^{1}$, Xuemei Wang ${ }^{2}$, Jason Blake Cohen ${ }^{2}$, Shengzhen Zhou ${ }^{2}$, Zhisheng Zhang ${ }^{3}$, Ming Chang ${ }^{1}$, and \\ Chuen-Yu Chan ${ }^{4}$ \\ ${ }^{1}$ School of Environmental Science and Engineering, Sun Yat-sen University, Guangzhou, China \\ ${ }^{2}$ School of Atmospheric Sciences, Sun Yat-sen University, Guangzhou, China \\ ${ }^{3}$ South China Institute of Environmental Sciences, Guangzhou, China \\ ${ }^{4}$ Key Laboratory of Aerosol, SKLLQG, Institute of Earth Environment, Chinese Academy of Sciences, Xi'an, China \\ Correspondence to: Xuemei Wang (eeswxm@mail.sysu.edu.cn) and Shengzhen Zhou (zszking@126.com)
}

Received: 10 May 2016 - Published in Atmos. Chem. Phys. Discuss.: 13 May 2016

Revised: 27 September 2016 - Accepted: 7 October 2016 - Published: 28 October 2016

\begin{abstract}
Measurements of size-resolved aerosols from 0.25 to $18 \mu \mathrm{m}$ were conducted at three sites (urban, suburban and background sites) and used in tandem with an atmospheric transport model to study the size distribution and formation of atmospheric aerosols in southern China during the monsoon season (May-June) in 2010. The mass distribution showed the majority of chemical components were found in the smaller size bins $(<2.5 \mu \mathrm{m})$. Sulfate was found to be strongly correlated with aerosol water and anticorrelated with atmospheric $\mathrm{SO}_{2}$, hinting at aqueous-phase reactions being the main formation pathway. Nitrate was the only major species that showed a bimodal distribution at the urban site and was dominated by the coarse mode in the other two sites, suggesting that an important component of nitrate formation is chloride depletion of sea salt transported from the South China Sea. In addition to these aqueous-phase reactions and interactions with sea salt aerosols, new particle formation, chemical aging, and long-range transport from upwind urban or biomass burning regions was also found to be important in at least some of the sites on some of the days. This work therefore summarizes the different mechanisms that significantly impact the aerosol chemical composition during the monsoon over southern China.
\end{abstract}

\section{Introduction}

Atmospheric aerosols are solid and liquid substances ubiquitously suspended in the Earth's atmosphere that impair visibility, negatively affect human health, and directly and indirectly impact regional and global climate (Burnett et al., 2014; Chen et al., 2013a; Chung and Seinfeld, 2005; Cohen et al., 2011; Huang et al., 2014; Jacobson, 2001; Kim et al., 2008; Liu et al., 2011; Ramanathan and Carmichael, 2008; Rosenfeld et al., 2014; Tao et al., 2009). The size distributions and chemical composition of aerosols play essential roles in their transport, transformation, and removal mechanisms (Cohen and Prinn, 2011; Cohen and Wang, 2013; Delene and Ogren, 2002; Dubovik et al., 2000; Giglio et al., 2003, 2006; Petrenko, et al., 2012; Seinfeld and Pandis, 2006; Zhao and Gao, 2008a). Additionally, to some extent, they provide useful information to validate and improve model performance (Cohen and Wang, 2013; Cohen, 2014; Cohen and Lecoeur, 2015; Myhre et al., 2013; Pillai and Moorthy, 2001; Schuster et al., 2006; Tsigaridis et al., 2014). In the environment, the most important aerosol processes occur over the Aitken $(<0.1 \mu \mathrm{m})$, condensation $(\sim 0.1-0.5 \mu \mathrm{m})$, droplet $(\sim 0.5-2.0 \mu \mathrm{m})$, and coarse $(>2.0 \mu \mathrm{m})$ size modes (Seinfeld and Pandis, 2006), where new particles are formed in the Aitken mode via condensational growth and coagulation of nucleation mode particles, and droplet mode particles are produced by in-cloud processing or aqueous reactions (Ervens et al., 2011; Lim et al., 2010; Meng and Seinfeld, 1994; Volkamer et al., 2009; Wang et al., 2012; Yao et 
al, 2003a). In contrast, coarse mode aerosols usually come from very different sources than smaller aerosols. For example, natural sources such as sea spray, dust, soil, and active biological aerosols are unique and therefore provide further information about the aerosol distribution at a given location.

Previous research suggests that sulfate is mostly contained in the non-coarse modes, with the conversion of $\mathrm{SO}_{2}$ occurring mostly via gas-phase oxidation followed by condensation or through droplet mode sulfate produced from fog/cloud process (Barth et al., 1992; Meng and Seinfeld, 1994). In contrast, nitrate usually has a bimodal distribution with peaks in both the fine and coarse modes. Fine mode nitrate is formed mainly by oxidation of $\mathrm{NO}_{2}$ to $\mathrm{HNO}_{3}$ and subsequent condensation or from the heterogeneous hydrolysis of $\mathrm{N}_{2} \mathrm{O}_{5}$, while coarse mode nitrate is often observed due to the effect of chloride depletion of sea salt aerosols (Harrison and Pio, 1983; Pierson and Brachaczek, 1998). Ammonium is mostly found in the fine mode and is chemically associated with sulfate and nitrate. Carbonaceous materials, organic carbon (OC) and elemental carbon (EC), are found primarily in the non-coarse mode. While both OC and EC are impacted by differing emissions sources and wet deposition, there are other significant differences: EC is hydrophobic and radiatively active, while OC is hydrophilic and further has significant source terms from condensation and secondary particle formation (Lan et al., 2011).

A series of studies about the mass size distribution of aerosol chemical components have been conducted at a specific site over southern China during the past decade (Lan et al., 2011; Liu et al., 2008; Yang and Wenig, 2009; Zhang et al., 2015). Compared with the previous studies, this paper presents a unique combination of analytical and measurement techniques. We use measurements of chemical properties and size distribution conducted at three different functional sites, coupled with multiple modeling results and reprocess remote sensing products using statistical methods, all in tandem with each other, which is not commonly found in other studies. Furthermore, we test our approach in southern China, which is one of the regions of the world with the most complex meteorology, coming under the influence of the monsoon, with shifting winds from continental and oceanic sources. Additionally, the season tested is a transition period, during which there were significant meteorological contributions from both remote continental sources and oceanic sources. On top of this, southern China has a combination of high temperature and relative humidity, strong radiative flux, and high oxidative capacity, leading to the promotion of significant secondary aerosol formation.

In this paper, we present a unique database of the sizedifferent mass distribution of aerosol chemical components during the monsoon season over southern China. The data were sampled from a combination of three different sites, one in an urban area, one in a suburban area, and one in a remote area, providing further insights into the characteristics of size distribution in each of these regions and discussion on the secondary aerosol formation mechanisms, the identification and impacts of long-range transport of biomass and urban sources, and the impacts of mixing sea salt and urban pollutants on the characteristics of aerosol size distribution.

\section{Measurements and methodology}

\subsection{Description of the sampling sites}

The field study was conducted at three sites in southern China (Fig. 1), two of which were situated in Guangdong and the other in Hainan. Guangdong is located in a subtropical monsoon climate, primarily influenced by cold and dry air masses from the north in December to February and by warm and wet air masses from the South China Sea in May to August. It has a single annual local rainy season extending from April to September. Hainan is located further to the south and has year-round warm to hot weather and a distinct rainy season from May to October.

The first site $\left(23.12^{\circ} \mathrm{N}, 113.36^{\circ} \mathrm{E}\right)$ is located on the rooftop of a building in the South China Institute of Environmental Sciences, Guangzhou (GZ), a megacity containing more than 13 million people. The site was located about $50 \mathrm{~m}$ above ground, in an area surrounded by residential and commercial buildings, with the nearest arterial roads located about $200 \mathrm{~m}$ away. There were no significant industrial emission sources found around the site. This site was chosen since it is highly representative of a typical megacity.

The second site was located at $22.34^{\circ} \mathrm{N}, 113.58^{\circ} \mathrm{E}$ on the rooftop of the library at Sun Yat-sen University in the city of Zhuhai (ZH), a medium-sized city of about 1.6 million people located in southern Guangdong adjacent to Macau. The site was located about $60 \mathrm{~m}$ above the ground, in an area surrounded by mountains on three sides and the estuary where the Pearl River meets the South China Sea about $500 \mathrm{~m}$ away on the fourth side. There are no significant industrial or major transportation emissions sources nearby. This site was chosen since it is highly representative of a coastal partially urbanized area.

The third site was located at Jianfeng Mountain (JFM; $18.74^{\circ} \mathrm{N}, 108.86^{\circ} \mathrm{E}$ ), in a tropical rainforest situated in the southwestern corner of Hainan. This site is distant from the major cities of Hainan province and is further located about $5 \mathrm{~km}$ away from the coast. JFM is not directly influenced by anthropogenic emissions and is generally regarded as a background site to investigate the long-range transport (Zhang et al., 2013a). This site was chosen both because it is representative of a remote site and because it receives air masses from three different directions: continental East Asia to the north, the South China Sea to the south, and Southeast Asia to the west. 

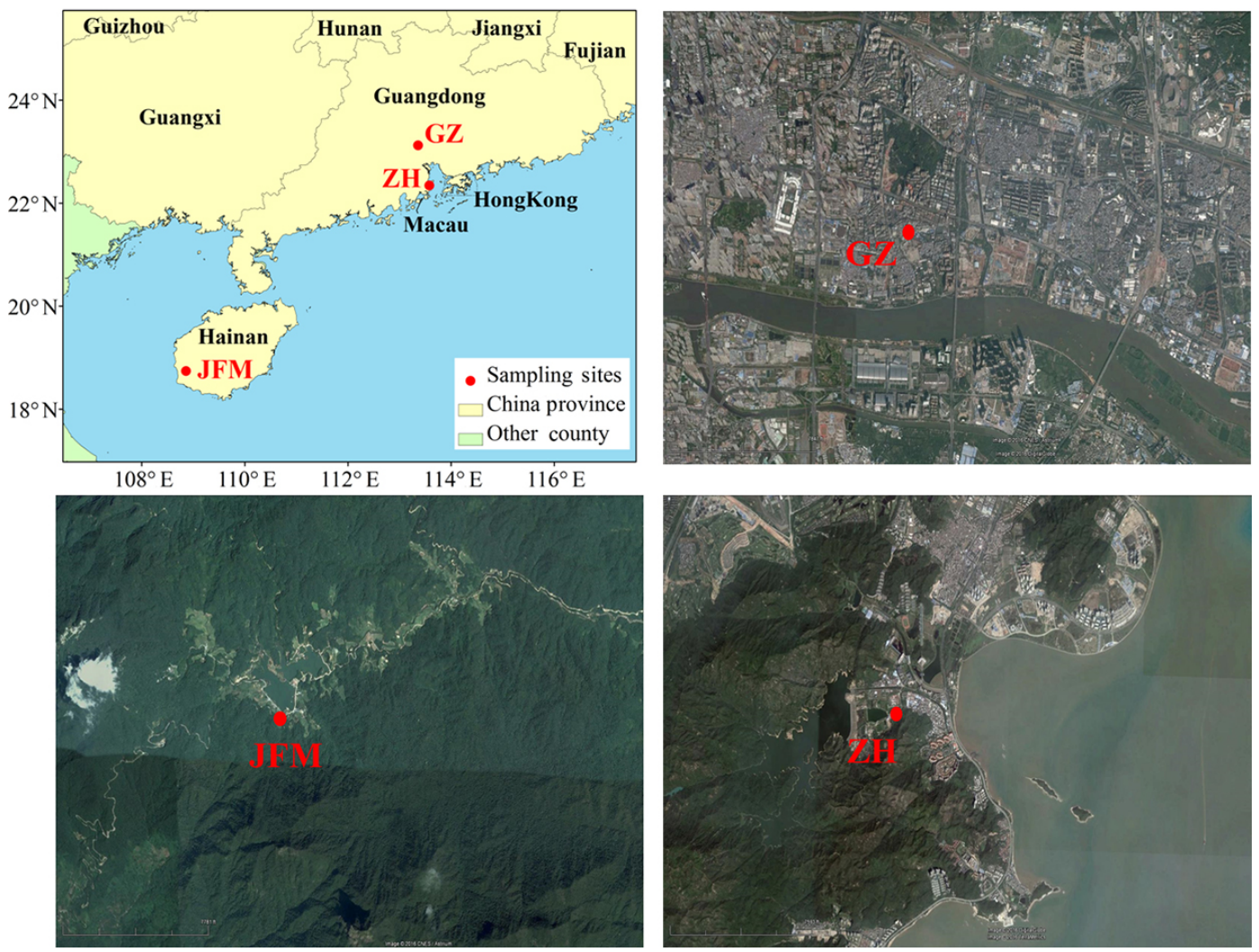

Figure 1. Location of sampling sites in southern China: GZ (Guangzhou), ZH (Zhuhai), and JFM (Jianfeng Mountain) and their surrounding environments.

\subsection{Sampling of aerosol}

To attain size-segregated particle samples, a six-stage high flow impactor (MSP) with an airflow rate of $100 \mathrm{~L} \mathrm{~min}^{-1}$ was employed, with cutoff diameters $\left(D_{p}\right)$ of 18 (inlet), 10, 2.5, $1.4,1.0,0.44$, and $0.25 \mu \mathrm{m}$. A total of 10,8 , and 20 sets of size-segregated particle samples were collected in GZ, ZH, and JFM, respectively, during the periods of May and June in 2010 (shown in Fig. 2). A single set of sample collection lasted for approximately $24 \mathrm{~h}$ in GZ and ZH and $48 \mathrm{~h}$ in JFM. Since the aerosol concentration was relatively low in remote JFM site, we extended the sampling time as long as $48 \mathrm{~h}$ to allow the chemical components to be detected.

The mass concentrations of six cations $\left(\mathrm{Na}^{+}, \mathrm{NH}_{4}^{+}, \mathrm{K}^{+}\right.$, $\mathrm{Ca}^{2+}, \mathrm{Mg}^{2+}$, and $\left.\mathrm{Ca}^{2+}\right)$ and seven anions $\left(\mathrm{F}^{-}, \mathrm{Cl}^{-}, \mathrm{NO}_{2}^{-}\right.$, $\mathrm{Br}^{-}, \mathrm{SO}_{4}^{2-}, \mathrm{NO}_{3}^{-}$, and $\mathrm{PO}_{4}^{-}$) were analyzed using ion chromatography (ICS-3000, DIONEX). Thermal optical transmittance (TOT) technique was employed to analyze the quartz filter samples to determine the mass concentrations of OC and EC by the use of Sunset Laboratory OCEC Carbon Aerosol Analyzer. Detailed information of the aerosol sampling and in-lab chemical analytical techniques can be found in Zhang et al. (2013a).

To be consistent with the background literature (four modes include Aitken $(<0.1 \mu \mathrm{m})$, condensation $(\sim 0.1-$
$0.5 \mu \mathrm{m})$, droplet $(\sim 0.5-2.0 \mu \mathrm{m})$, and coarse $(>2.0 \mu \mathrm{m})$; Seinfeld and Pandis, 2006) and the constraints of the size bins measured in this study, we implement $2.5 \mu \mathrm{m}$ as the cutoff size to separate fine and coarse particles, and the size bins from 0.44 to $1.4 \mu \mathrm{m}$ were defined as droplet particles in this study. Although we were not able to directly measure aerosol water content, given its importance for the study here, we instead estimate the amount by the use of E-AIM model II (Clegg et al., 1998), as it provides the most accurate prediction compared with other models, like ISORROPIA and SCAPE2 (Yao et al., 2006). The input parameters of the EAIM model II are temperature, relative humidity, strong acidity $\left(\mathrm{H}^{+}\right)$, and molar concentrations of $\mathrm{NH}_{4}^{+}, \mathrm{SO}_{4}^{2-}$, and $\mathrm{NO}_{3}^{-}$ ions (Clegg et al., 1998). Further, an approximation of the particle strong acidity $\left[\mathrm{H}^{+}\right]_{\mathrm{s}}$ was calculated using Eq. (1):

$\left[\mathrm{H}^{+}\right]_{\mathrm{s}}=2\left[\mathrm{SO}_{4}^{2-}\right]+\left[\mathrm{NO}_{3}^{-}\right]-\left[\mathrm{NH}_{4}^{+}\right]$.

The calculation of strong acidity would introduce possible errors due to the exclusion of other ions (e.g., $\mathrm{K}^{+}, \mathrm{Na}^{+}, \mathrm{Cl}^{-}$), which only exerted a minor influence on the estimation of aerosol acidity due to their lower concentration (Yao et al., 2006). 

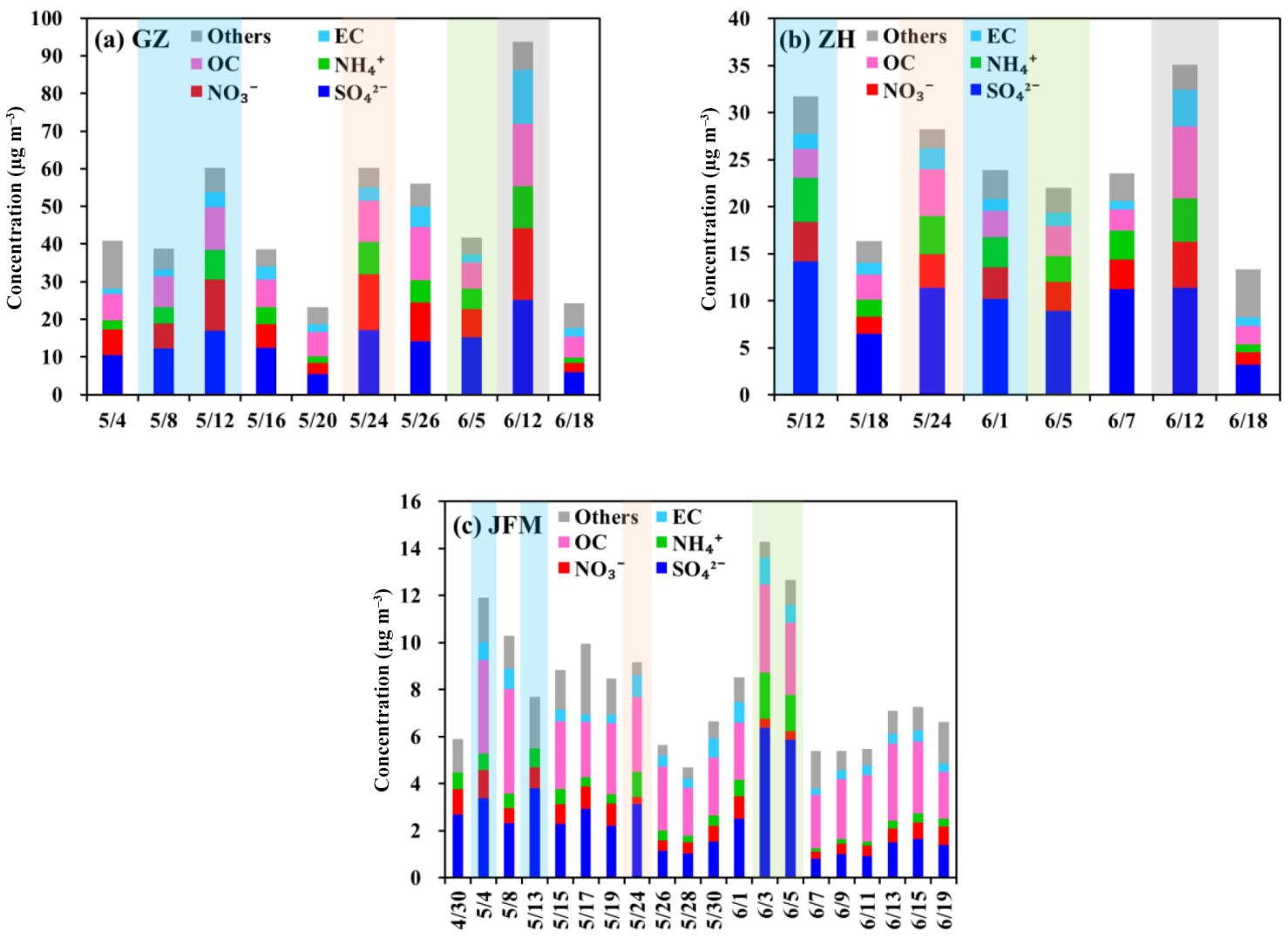

Figure 2. Time series of $\mathrm{PM}_{18}$ chemical compositions at the three sites during the 2010 wet season.

\subsection{Meteorological data}

Meteorological parameters, including wind speed (WS), wind direction (WD), temperature $(T)$, relative humidity $(\mathrm{RH})$, pressure $(P)$, and precipitation, were simultaneously monitored in GZ and JFM sites with a time resolution of $30 \mathrm{~min}$. The same meteorological parameters in $\mathrm{ZH}$, as well as the daily low-level cloud cover data at all three sites, were obtained from the China Meteorological Data Sharing Service System (http://data.cma.cn/site/index.html).

\subsection{Remotely sensed measurements}

Aerosol optical depth (AOD), fire products including fire radiative power (FRP), and fire quality assurance (QA) data were obtained from the MODIS sensors aboard both the AQUA and TERRA satellites. Specifically, we obtained the Collection 6, $3 \mathrm{~km}$ Level 2 swath product for AOD (Remer et al., 2013) and Collection 5.1, $1 \mathrm{~km}$ Level 2 swath products for FRP and QA (Giglio et al., 2006). The Collection 5.1 active fire products are daily products and have been improved based on the previous collection 5.0 products. All of the data are cloud-screened, with AOD data being computed using different algorithms over land and water, and the fire data using 19 different channels for quality assurance. We only accept values for FRP and fire count where the QA is at least $90 \%$.

\subsection{Atmospheric transport model}

Two Lagrangian particle dispersion models, the Hybrid Single Particle Lagrangian Integrated Trajectory (HYSPLIT; Draxler and Hes, 1998) and FLEXPART coupled with the Weather and Research and Forecasting (WRF) model (FLEXPART-WRF; Stohl et al., 1998; Brioude et al., 2013), were applied to determine the origin of air masses in this study. Compared with HYSPLIT, FLEXPART can identify the relative importance of the source region that affected the receptor visually. HYSPLIT uses single air parcels to compute trajectories with the use of Global Data Assimilation System $\left(\mathrm{GDAS}, 1^{\circ} \times 1^{\circ}\right.$ ) as input data. FLEXPART, however, uses a larger number of air parcels to compute trajectories based on the higher-resolution meteorological predictions provided by mesoscale model WRF (Skamarock et al., 2008). The application of FLEXPART-WRF with an added novel convective scheme improves the dispersion simulations and results in an overall better simulation, especially for finer-scale applications (Brioude et al., 2013; Stohl, 1998). In this case, the region was modeled with a spatial resolution of $27 \times 27 \mathrm{~km}$ and a temporal resolution of $1 \mathrm{~h}$. 
Table 1. Average concentration and standard deviation $\left(\mu \mathrm{g} \mathrm{m}^{-3}\right)$ of chemical components in the given size-resolved particles (and their percentage of $\mathrm{PM}_{10}$ ) at the three sites during the 2010 wet season.

\begin{tabular}{llrrrrrr}
\hline Site & Size & $\begin{array}{r}\text { Sum of } \\
\text { measured species }\end{array}$ & $\mathrm{SO}_{4}^{2-}$ & $\mathrm{NO}_{3}^{-}$ & $\mathrm{NH}_{4}^{+}$ & $\mathrm{OC}$ & $\mathrm{EC}$ \\
& & & & & & \\
\hline $\mathrm{GZ}$ & $\mathrm{PM}_{1.0}$ & $24.4 \pm 10.9$ & $8.0 \pm 3.1$ & $3.0 \pm 2.4$ & $3.4 \pm 1.7$ & $5.5 \pm 2.0$ & $2.9 \pm 2.6$ \\
& & & $(60.2)$ & $(34.5)$ & $(64.2)$ & $(57.9)$ & $(72.5)$ \\
& $\mathrm{PM}_{2.5}$ & $34.9 \pm 17.3$ & $11.7 \pm 5.2$ & $5.0 \pm 4.0$ & $4.9 \pm 2.9$ & $7.2 \pm 2.7$ & $3.4 \pm 3.2$ \\
& & & $(88.0)$ & $(57.5)$ & $(92.5)$ & $(75.8)$ & $(85.0)$ \\
& $\mathrm{PM}_{10}$ & $46.7 \pm 20.6$ & $13.3 \pm 5.8$ & $8.7 \pm 5.2$ & $5.3 \pm 3.1$ & $9.5 \pm 3.7$ & $4 \pm 3.8$ \\
\hline $\mathrm{ZH}$ & $\mathrm{PM}_{1.0}$ & $12.9 \pm 4.5$ & $6.3 \pm 2.1$ & $0.3 \pm 0.3$ & $2.2 \pm 0.8$ & $2.4 \pm 1.1$ & $1.3 \pm 0.8$ \\
& & & $(66.3)$ & $(10.3)$ & $(71.0)$ & $(66.7)$ & $(76.5)$ \\
& $\mathrm{PM}_{2.5}$ & $18.1 \pm 6.8$ & $8.8 \pm 3.2$ & $0.9 \pm 0.8$ & $3.0 \pm 1.2$ & $3.0 \pm 1.5$ & $1.5 \pm 0.9$ \\
& & & $(92.6)$ & $(31.0)$ & $(96.8)$ & $(83.3)$ & $(88.2)$ \\
& $\mathrm{PM}_{10}$ & $23.7 \pm 7.3$ & $9.5 \pm 3.4$ & $2.9 \pm 1.1$ & $3.1 \pm 1.3$ & $3.6 \pm 1.9$ & $1.7 \pm 1.0$ \\
\hline $\mathrm{JFM}$ & $\mathrm{PM}_{1.0}$ & $4.4 \pm 1.6$ & $1.8 \pm 1.0$ & $0.1 \pm 0.1$ & $0.5 \pm 0.3$ & $1.5 \pm 0.7$ & $0.3 \pm 0.2$ \\
& & & $(75.0)$ & $(16.7)$ & $(83.3)$ & $(57.7)$ & $(60.0)$ \\
& $\mathrm{PM}_{2.5}$ & $5.8 \pm 2.3$ & $2.2 \pm 1.5$ & $0.2 \pm 0.1$ & $0.6 \pm 0.5$ & $1.8 \pm 0.8$ & $0.4 \pm 0.2$ \\
& & & $(91.7)$ & $(33.3)$ & $(99.0)$ & $(69.2)$ & $(80.0)$ \\
& $\mathrm{PM}_{10}$ & $8.0 \pm 2.6$ & $2.4 \pm 1.5$ & $0.6 \pm 0.3$ & $0.6 \pm 0.5$ & $2.6 \pm 1.1$ & $0.5 \pm 0.3$ \\
\hline & & & & & & &
\end{tabular}

A Eulerian model, WRF/Chem V3.4.1 (Grell et al., 2005), was used in this study to simulate the fog process. For this model, the target region was modeled at a spatial resolution of $3 \times 3 \mathrm{~km}$ and a temporal resolution of $1 \mathrm{~h}$. Detailed information about the WRF/Chem model setup is described in Situ et al. (2013).

\section{Results and discussion}

\subsection{Overall aerosol characteristics}

The time series of $\mathrm{PM}_{18}$ chemical compositions at the three sites during the sampling period are shown in Fig. 2. The average concentration and standard deviation of $\mathrm{PM}_{18}$ were $47.8 \pm 20.8,24.3 \pm 12.1$, and $8.1 \pm 2.7 \mu \mathrm{g} \mathrm{m}^{-3}$ in $\mathrm{GZ}, \mathrm{ZH}$, and JFM, respectively. The mean and range of $\mathrm{PM}_{18}$ in highly urban GZ was both higher and wider than in suburban $\mathrm{ZH}$ and rural JFM, with the respective ranges of 23.3-93.7,

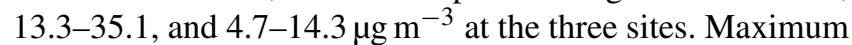
concentration was found on 12 June in both GZ and ZH and on 3 June in JFM (to be discussed later).

Table 1 listed the average concentration of chemical components in the given size-resolved particle $\left(\mathrm{PM}_{1.0}, \mathrm{PM}_{2.5}\right.$, and $\left.\mathrm{PM}_{10}\right)$ and their percentage of $\mathrm{PM}_{10}$ at the three sites. In terms of the mass size distribution, the percentage of $\mathrm{PM}_{1.0}$ to $\mathrm{PM}_{10}$ was $60.2,66.3$, and $75.0 \%$, and that of $\mathrm{PM}_{2.5}$ to $\mathrm{PM}_{10}$ was $88.0,92.6,91.7 \%$ in $\mathrm{GZ}, \mathrm{ZH}$, and JFM, respectively. When considered as a whole, it is the smallersized particles that dominate the aerosol loading at all three of these sites. Looking at the data on a species-by-species level, most of chemical components were concentrated in fine mode particles, which contribute at least $57 \%$ to $\mathrm{PM}_{2.5}$.
The sole exception is nitrate at $\mathrm{ZH}$ and JFM, which was mainly concentrated in the coarse mode with a percentage of above $90 \%$. Overall, the sum of five major chemical components (i.e., sulfate, nitrate, ammonium, OC, and EC) accounted for about $90 \%$ of the total mass concentration of detected chemical components across all three sites.

Two of the species, sulfate and OC, were found to dominate the particle composition, with concentrations of $11.7 \pm 5.2,8.8 \pm 3.2$, and $2.2 \pm 1.5 \mu \mathrm{g} \mathrm{m}^{-3}$ for sulfate and $7.2 \pm 2.7,3.0 \pm 1.5$, and $1.8 \pm 0.8 \mu \mathrm{g} \mathrm{m}^{-3}$ for $\mathrm{OC}$ in GZ, $\mathrm{ZH}$, and JFM, respectively. Sulfate concentration was much higher than that of OC in urban and suburban locations irrespective of particle size, while OC concentration was similar to that of sulfate in fine particles and slightly higher in coarse particles at the remote site. These findings are consistent with the nature of the sources of sulfur from industrial and power plant (Zheng et al., 2009). In addition, shipping source was becoming increasingly vital for $\mathrm{SO}_{2}$ emission with an increment of $12 \%$ per year in this region (Lu et al., 2013; Zhou et al., 2016)

Nitrate, mainly formed from the oxidation of $\mathrm{NO}_{x}$ emitted by mobile vehicles and power plants, showed a remarkable difference between urban and background sites, ranging from 14 to 30 times higher in GZ than in the other sites, especially for fine mode nitrate. This is consistent with its more rapid oxidation of its abundant precursor species, especially so in the urban atmosphere (Cohen et al., 2011). In addition, phase equilibrium was another important reason for the discrepancy in urban and background site since nitrate would tend to exist as gas phase while transported to background areas (Seinfeld and Pandis, 2006). A relatively insignificant 
concentration of $\mathrm{NO}_{3}^{-}$in $\mathrm{ZH}$ and JFM indicated far less anthropogenic emission of the precursor over these two sites.

The values of $\mathrm{OC}$ and $\mathrm{EC}$ in $\mathrm{PM}_{2.5}$ were $7.2 \pm 2.7$ and $3.4 \pm 3.2 \mu \mathrm{g} \mathrm{m}^{-3}$ in GZ and $3.0 \pm 1.5$ and $1.5 \pm 0.9 \mu \mathrm{g} \mathrm{m}^{-3}$ in $\mathrm{ZH}$. These values were lower than those found in previous studies done in $\mathrm{GZ}$ and $\mathrm{ZH}$ during the wet season: $\mathrm{OC}$ and EC were 13.1 and $4.6 \mu \mathrm{g} \mathrm{m}^{3}$ in GZ in 2007, 14.8 and $8.1 \mu \mathrm{g} \mathrm{m}^{-3}$ in $\mathrm{GZ}$ in 2002 , and 5.4 and $1.9 \mu \mathrm{g} \mathrm{m}^{-3}$ in $\mathrm{ZH}$ in 2002 (Cao et al., 2004; Tao et al., 2009). Furthermore, OC and EC concentrations in JFM were found to be lower than that at other forest sites in China, such as Hengshan (3.01 and $0.54 \mu \mathrm{g} \mathrm{m}^{-3}$ in 2009; Zhou et al., 2012), Daihai (8.1 and $1.81 \mathrm{\mu g} \mathrm{m}^{-3}$ in 2007; Han et al., 2008), and Taishan (6.07 and $1.77 \mu \mathrm{g} \mathrm{m}^{-3}$ in 2007; Wang et al., 2011). However, the EC and OC in JFM were similar to some background sites in other countries, such as Puy De Dôme in France (2.4 and $0.26 \mu \mathrm{g} \mathrm{m}^{-3}$ in 2004; Pio et al., 2007) and Sonnblick in Austria (1.38 and $0.23 \mu \mathrm{g} \mathrm{m}^{-3}$ in 2003; Pio et al., 2007). This finding is not unexpected since there are very few urban sources near the site. It is therefore relatively representative of a remote background site and will be treated as such subsequently in this paper.

\subsection{Size distribution by chemical composition}

The mass size distribution of major compositions at the three sites during the study period shows that sulfate had a single-peaked distribution, with the maximum value found in the $0.44-1.0 \mu \mathrm{m}$ size over all sites and under all different meteorological conditions examined in this study. The droplet mode sulfate was about $56.0 \pm 8.0,63.5 \pm 5.1$, and $58.8 \pm 9.4$ of the total sulfate mass in GZ, ZH, and JFM, respectively (Fig. 3). This confirms that secondary processing is essential, with aqueous-phase reactions playing a crucial role on the formation and/or growth of droplet sulfate throughout all of these different regions. It is interesting to note that $\mathrm{ZH}$ had the highest relative concentration of droplet-model sulfate, which, although less urban than GZ, is consistent with the fact that it is located very close to large amounts of sulfur emissions from the shipping traffic at the massive nearby ports of Hong Kong and Shenzhen (Lu et al., 2013).

Droplet mode ammonium was mainly due to ammonia vapor that reacted with or condensed on an acidic particle surface. Ammonia was observed to highly correlate with sulfate at the three sites $(R>0.81, P<0.01)$, particularly so in the size range of $0.44-1.0 \mu \mathrm{m}$. This is consistent with the fact that sulfuric acid preferentially reacts with ammonia (Zhuang et al., 1999) and that most of sulfate in the atmosphere is generally found as ammonium sulfate in the droplet mode (Liu et al., 2008; Zhuang et al., 1999).

The nitrate size distribution was found to be bimodal in GZ, with the peaks occurring in the $0.44-1.0$ and $2.5-10 \mu \mathrm{m}$ size ranges. This is consistent with the fact that droplet mode nitrate was dominated by the heterogeneous aqueous reaction of gaseous nitric acid $\left(\mathrm{HNO}_{3}\right)$ and ammonia $\left(\mathrm{NH}_{3}\right)$ on the wet surfaces of pre-existing aerosols within ammonia-rich environment; however, the droplet mode nitrate was formed by heterogeneous hydrolysis of $\mathrm{N}_{2} \mathrm{O}_{5}$ on the pre-existing aerosols within ammonia-poor conditions. The dissociation equilibrium of $\mathrm{NH}_{4} \mathrm{NO}_{3}$ highly depends on temperature and humidity (Stelson and Seinfeld, 1982). However, this result is consistent with the fact that nitrate was found mostly in the coarse mode in $\mathrm{ZH}$ and JFM, where it accounted for up to $60 \%$ of total particulate mass. A higher relative humidity, consistent with the warm and wet atmosphere over the South China Sea, makes gaseous nitric acid more likely to be absorbed by coarse particles in the atmosphere (Anlauf et al., 2006), resulting in a higher relative concentration of nitrate in the coarse mode in ZH and JFM (where the relative humidity averaged 80 and $91 \%$, respectively, as compared to only $73 \%$ in GZ). Further, the presence of coarse mode nitrate is consistent with chlorine reduction, as talked about later.

OC and EC showed a similar monomodal distribution in $\mathrm{GZ}$ and $\mathrm{ZH}$, with a dominant and a broad peak over the range from 0.25 to $1.4 \mu \mathrm{m}$. In contrast, a bimodal distribution was found in JFM. In urban and suburban areas, there are significant primary sources from traffic and industry (e.g., Huang et al., 2006, and Cao et al., 2004). It is also consistent with the high-level emissions due to the ship traffic to Shenzhen and Hong Kong, both of which are located near $\mathrm{ZH}$, which in turn would compensate for the otherwise reduced industrial and traffic sources (Zheng et al., 2012). OC has both primary sources, which are similar to those for EC as well as secondary formation. There were a few days in which the ratios of OC to EC are not consistent, indicating a large secondary source of OC. We investigated these days and find that emissions that transported from far-upwind areas with highly urbanization or with the existence of biomass burning are responsible, as discussed later in this paper. Additionally, there is some coarse mode OC present in JFM, suggesting a possible source of biological aerosol (e.g., pollen, spores, and plant fragment; Heald and Spracklen, 2009; Seinfeld and Pandis, 2006; Zhang et al., 2015), which is consistent with the large amounts of vegetation present in that region (Zhang et al., 2015).

\subsection{Observed aqueous-phase reaction of droplet mode sulfate}

The daily droplet mode sulfate ranged from 3.0 to $13.6,1.6$ to 9.5, and 0.5 to $4.9 \mu \mathrm{g} \mathrm{m}^{-3}$ in GZ, ZH, and JFM, respectively. In order to study the aqueous-phase reaction of droplet mode sulfate, cases with the air masses came from continental direction were excluded to avoid the effect of transported pollutants on the concentration of sulfate. Then two cases with a concentration of droplet sulfate above the mean plus 1 standard deviation were selected as typical cases at each site (8 and 12 May in GZ, 12 May and 1 June in ZH, and 4 and 13 May 2010 in JFM), which were more obvious to observe 

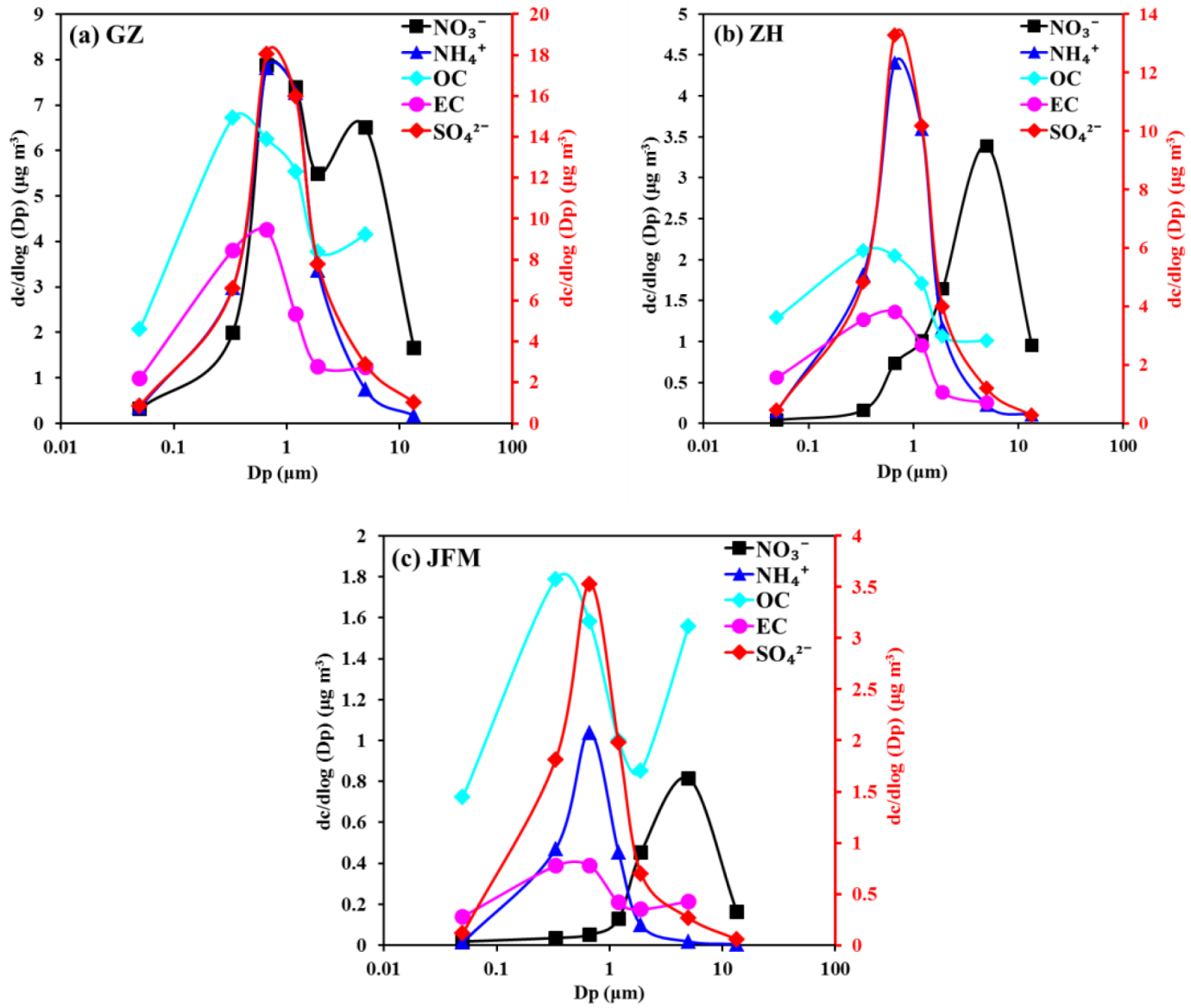

Figure 3. The mass size distribution of major compositions $\left(\mathrm{SO}_{4}^{2-}, \mathrm{NO}_{3}^{-}, \mathrm{NH}_{4}^{+}, \mathrm{OC}\right.$, and $\left.\mathrm{EC}\right)$ at the three sites during study period $\left(\mathrm{SO}_{4}^{2-}\right.$ is plotted against the right $y$ axes).

Table 2. Statistical parameters of samples with air masses from ocean.

\begin{tabular}{llccccccr}
\hline Site & Date & $\begin{array}{c}\text { Droplet } \\
\text { sulfate } \\
\text { mode }\left(\mu \mathrm{g} \mathrm{m}^{-3}\right)\end{array}$ & $\begin{array}{c}\text { Percentage of } \\
\text { sulfate in } \\
\text { droplet mode }(\%)\end{array}$ & $\begin{array}{c}T \\
\left(^{\circ}\right)\end{array}$ & $\begin{array}{r}\mathrm{RH} \\
(\%)\end{array}$ & $\begin{array}{r}P \\
(\mathrm{hPa})\end{array}$ & $\begin{array}{r}\text { WS } \\
\left(\mathrm{m} \mathrm{s}^{-1}\right)\end{array}$ & $\begin{array}{r}\text { Low } \\
\text { cloud cover } \\
(\%)\end{array}$ \\
\hline $\mathrm{GZ}$ & $2010 / 5 / 8$ & 7.4 & 61 & 27.5 & 82.0 & 997.1 & 1.9 & 70 \\
& $2010 / 5 / 12$ & 11.1 & 65 & 25.0 & 77.5 & 1002.9 & 1.5 & 60 \\
\hline $\mathrm{ZH}$ & $2010 / 5 / 12$ & 9.5 & 67 & 24.9 & 83.0 & 1006.1 & 3.4 & 70 \\
& $2010 / 6 / 1$ & 6.8 & 67 & 24.8 & 80.0 & 1002.0 & 5.1 & 70 \\
\hline JFM & $2010 / 5 / 4$ & 2.2 & 64 & 22.0 & 83.0 & 916.9 & 1.0 & 70 \\
& $2010 / 5 / 13$ & 2.5 & 67 & 23.7 & 75.8 & 918.3 & 1.8 & 70 \\
\hline
\end{tabular}

and further were applied to investigate the effect of aqueousphase reaction in the formation of droplet mode sulfate (blue shade in Fig. 2). In each of these cases, it was found that droplet mode sulfate accounted for about two-thirds of the total mass concentration of sulfate at the three sites.

A backward trajectory analysis found that during these events, the air masses at these sites mainly originated over the South China Sea (figures not shown here). Additionally, it was determined that during these times at the three sites, there was an abnormally high amount of low cloud cover 60 $70 \%$ and higher relative humidity (75-83\%; Table 2 ). This combination is consistent with moist air being transported over land where the ship and industrial $\mathrm{SO}_{2}$ emissions can undergo chemistry in the presence of large amounts of liquid cloud water to form droplet-model sulfate. 

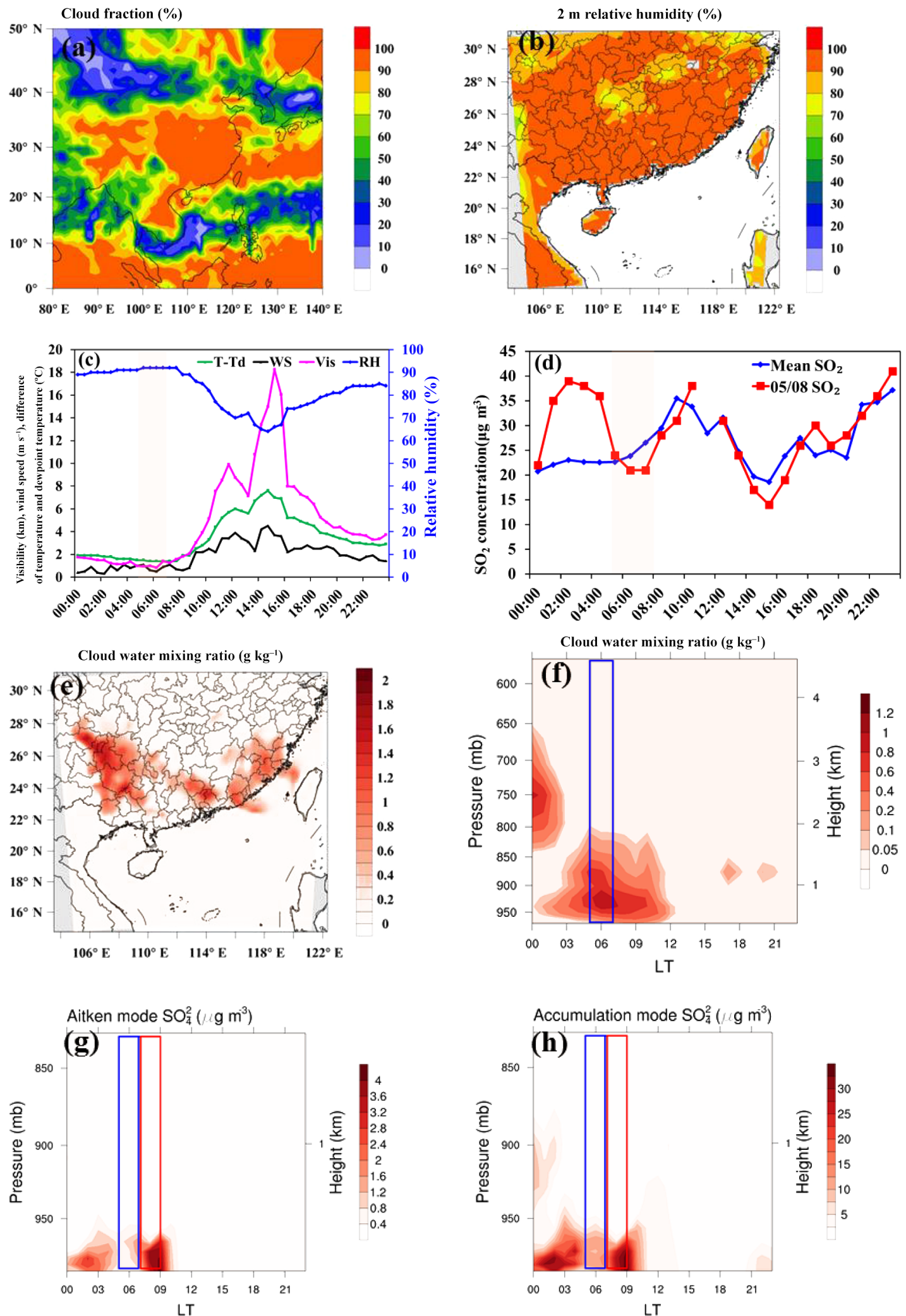

Figure 4. Case study on 8 May in GZ. (a) The cloud fraction over southern China. (b) Distribution of simulated average $2 \mathrm{~m}$ relative humidity at 05:00-07:00 LT. (c) The time series of observational visibility, wind speed, relative humidity, and the depression of dew point (time resolution was $30 \mathrm{~min}$ ). (d) The time series of monitored mean $\mathrm{SO}_{2}$ during 2009-2010 and $\mathrm{SO}_{2}$ on 8 May. (e) Distribution of simulated average cloud. (f) The time-height distribution of simulated cloud water mixing ratio on 8 May. (g-h) The time-height of simulated Aitken and accumulation mode $\mathrm{SO}_{4}^{2-}$. 
We estimated the liquid water content using the AIMII model (Eq. 1). The results showed a significant positive correlation with droplet mode sulfate in GZ $(R=0.98$, $P<0.05), \mathrm{ZH}(R=0.53, P<0.05)$, and JFM $(R=0.80$, $P<0.05)$, indicating that water content correlated closely with the sulfate aerosol loadings. This is further evidence that aqueous formation was likely an important contributing factor.

We further investigated the aqueous-phase reaction of particles due to the fog process for the data from 8 May in GZ. This is because the measured visibility met the World Meteorological Organization cutoff value of less than $1 \mathrm{~km}$ due to water droplets in the early morning (05:00-07:00 LT; Fig. 4c). Consistently, during this time, it was found that the relative humidity was quite high $(\mathrm{RH}>90 \%)$ and the wind was quite low (wind speeds $<1.0 \mathrm{~m} \mathrm{~s}^{-1}$ ). Also during this time, the cloud fraction and simulated $2 \mathrm{~m}$ relative humidity were up to $90 \%$ over southern China (Fig. 4a-b). Furthermore, the depression dew point $\left(\Delta T=T-T_{\mathrm{d}}\right.$, where $T_{\mathrm{d}}$ denotes dew point temperature) was lower than 1 (Fig. $4 \mathrm{c}$ ), which indicates that vapor pressure was saturated. An accompanying analysis using WRF/Chem shows that simulated cloud water mixing ratio was the highest during this period over the GZ area and higher value was found around 06:00 LT (Fig. 4e-f). This combination promoted the existence of fog/low cloud.

Further analysis was done by looking at measurements of $\mathrm{SO}_{2}$ (data from Guangzhou Environmental Protection Bureau, http://www.gzepb.gov.cn/). The diurnal variation on 8 May showed a unique pattern compared with the mean diurnal pattern as measured during 2009-2011 (Fig. 4d). On this day, the $\mathrm{SO}_{2}$ concentration has decreased dramatically since 05:00-07:00 LT, which is consistent with $\mathrm{SO}_{2}$ transferred from the gas to aqueous phase due to the high solubility of $\mathrm{SO}_{2}$ in fog water droplets (Zhang et al., 2013b).

Simulation of these conditions using WRF/Chem indicates that the rapid growth of both Aitken and accumulation $(\sim 0.1-1 \mu \mathrm{m})$ mode sulfate started at 07:00 LT and peaked at 08:00-09:00 LT (Fig. 4g-h). This further supports the conclusion of fresh sulfate production, in this case through both the aqueous and potential initial gas to particle formation, followed by condensation/coagulation and uptake into the liquid droplets present. All of this is consistent with generalized urban modeling studies performed under similar conditions (e.g., Cohen and Prinn, 2011).

\subsection{Observed interactions between nitrate and chloride depletion}

The mass size distribution of $\mathrm{Cl}^{-}$and $\mathrm{Na}^{+}$showed a similar pattern to nitrate at the three sites, peaking in coarse mode particles (Fig. 5a-c) with an average percentage of 43, 62 and $43 \%$ for coarse mode $\mathrm{Na}^{+}$and 53, 76, and $74 \%$ for coarse mode $\mathrm{Cl}^{-}$in $\mathrm{GZ}, \mathrm{ZH}$, and JFM, respectively, suggesting the main sea salt sources. $\mathrm{Na}^{+}$and $\mathrm{Cl}^{-}$showed a bimodal dis- tribution in GZ, illustrating the combustion emissions, e.g., biomass burning or coal combustion for fine mode $\mathrm{Na}^{+}$and $\mathrm{Cl}^{-}$(Wang et al., 2005), but the contributions were insignificant since the magnitude of $\mathrm{Na}^{+}$and $\mathrm{Cl}^{-}$from combustion sources is many orders of magnitude smaller than oceanic sources. Furthermore, if the biomass burning source were significant, it would clearly also show up in terms of the $\mathrm{K}^{+}$ and BC / OC ratio, as explained later in the Sect. 3.6.

The concentration and percentage of chloride depletion ( $\left[\mathrm{Cl}_{\mathrm{dep}}\right]$ and $\left.\% \mathrm{Cl}_{\mathrm{dep}}\right)$ were calculated using Eqs. (2-3), where $\left[\mathrm{Cl}_{\text {meas }}^{-}\right]$and $\left[\mathrm{Na}_{\text {meas }}^{+}\right]$are the measured molar concentrations of chloride and sodium, respectively, and 1.174 was the molar ratio of $\mathrm{Cl}^{-}$to $\mathrm{Na}^{+}$in seawater (Yao et al., 2003b).

$$
\begin{aligned}
& {\left[\mathrm{Cl}_{\text {dep }}\right]=1.174\left[\mathrm{Na}_{\text {meas }}^{+}\right]-\left[\mathrm{Cl}_{\text {meas }}^{-}\right]} \\
& \% \mathrm{Cl}_{\text {dep }}=\frac{1.174\left[\mathrm{Na}_{\text {meas }}^{+}\right]-\left[\mathrm{Cl}_{\text {meas }}^{-}\right]}{1.174\left[\mathrm{Na}_{\text {meas }}^{+}\right]} \times 100 \%
\end{aligned}
$$

The positive value of $\left[\mathrm{Cl}_{\mathrm{dep}}\right]$ represents chloride depletion, while the negative value indicates the chloride enrichment, suggesting additional sources existed for $\mathrm{Cl}^{-}$excluding sea salt. Therefore, samples with negative $\left[\mathrm{Cl}_{\mathrm{dep}}\right]$ were excluded from analysis to avoid the effect of non-sea-salt emission on chloride depletion.

In general, the $\% \mathrm{Cl}_{\mathrm{dep}}$ decreased as the aerosol size increased (Fig. 5d). Chloride had been almost entirely depleted in fine mode particles with the value of $91 \%$, while the value was $60 \%$ in coarse mode particles in ZH and JFM. The chloride depletion was relatively weaker in GZ, with a value of 72 and $47 \%$ in fine and coarse mode particle. The result was consistent with a study conducted in South China Sea in 2004 as well as the theory that the reaction of sulfuric acid and nitric acid with sea salt (sodium chloride) is facilitated in fine particles due to their larger ratio of surface area to volume and longer atmospheric residence time (Chatterjee et al., 2010; Hsu et al., 2007).

The ratio of calculated ammonium to measured ammonium was used to explain the presence of sulfuric acid and nitric acid in the aerosol with a value larger than 1, indicating there was insufficient ammonium to neutralize nitric acidic $\mathrm{NO}_{3}^{-}$(since ammonium first consumes sulfuric acid). Calculated ammonium was equal to $2 \times$ [nss$\left.\mathrm{SO}_{4}^{2-}\right]+\left[\mathrm{NO}_{3}^{-}\right]$, where $\left[\mathrm{nss}-\mathrm{SO}_{4}^{2-}\right]$ and $\left[\mathrm{NO}_{3}^{-}\right]$represents the molar concentration of non-sea-salt $\mathrm{SO}_{4}^{2-}$ (i.e., [nss$\left.\mathrm{SO}_{4}^{2-}\right]=\left[\mathrm{SO}_{4}^{2-}\right]-0.14 \times\left[\mathrm{Cl}^{-}\right]$) and $\mathrm{NO}_{3}^{-}$(Huang et al., 2004). The calculated ratio was much higher than 1 in $\mathrm{ZH}$ and JFM, suggesting that nitrate plays a role in $\mathrm{Cl}$ depletion. The ratio of nitrate to percent chloride depletion can then be used to calculate the contribution of coarse nitrate to chloride depletion (Zhuang et al., 1999; Zhao and Gao, 2008b). This result showed that nitrate was responsible for the depletion of 54 and $17 \%$ of coarse chloride in $\mathrm{ZH}$ and JFM, respectively. This suggests that the interaction of sea salt particles with anthropogenic pollutants is an important pathway for the generation of aerosol species in coastal suburban regions 

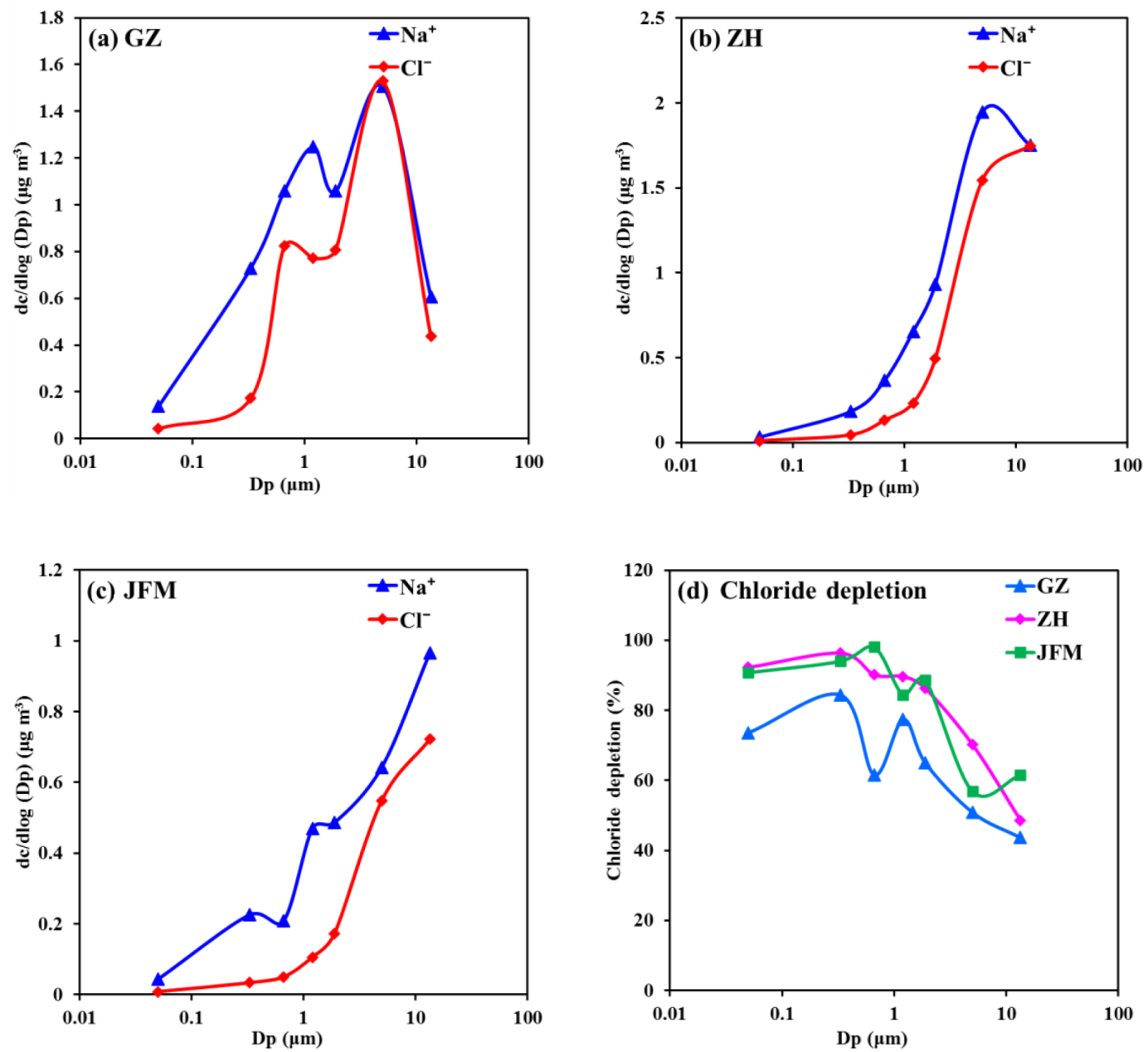

Figure 5. The mass size distribution of $(\mathbf{a}-\mathbf{c}) \mathrm{Na}^{+}$and $\mathrm{Cl}^{-}$and (d) percentage of chloride depletion at the three sites.

like $\mathrm{ZH}$, which have sizable amounts of both sea salt and $\mathrm{NO}_{x}$ emissions (Chatterjee et al., 2010; Liu et al., 2008).

Relative humidity exceeded $80 \%$ during the whole sampling time in $\mathrm{ZH}$ except for 24 May, during which it was $64 \%$, and the air massed mainly came from northern continental areas. The only other day that had a significant continental wind source at $\mathrm{ZH}$ with a higher relative humidity (80\%) was 7 June. The percentage of chloride depletion was 95 and $69 \%$ for fine and coarse particles on 24 May and the value was 78 and $64 \%$ on 7 June. There was no distinct difference found in coarse particles for the two cases, but there was a considerable difference in fine particles with higher chloride depletion occurring on 24 May. The meteorological conditions were similar on these 2 days, excluding humidity; moreover, the aerosol water content in fine mode particles was about 8 times higher on 7 June $\left(3.6 \mu \mathrm{g} \mathrm{m}^{-3}\right)$ than on 24 May $\left(0.45 \mu \mathrm{g} \mathrm{m}^{-3}\right)$. This finding suggested that humidity or aerosol water content would be an important factor that affected the chloride depletion, which is consistent with our understanding of the release of hydrochloric acid under the known high nitric acid conditions, especially when there is less aerosol water (at relatively lower humidity) to dissolve all of the volatiles, which would shift $\mathrm{HNO}_{3}$ from gas phase to particle phase and further reinforce the release of hydrochloric acid (Chen et al., 2013b; Dasgupta et al., 2007). In addition, the concentration of coarse mode nitrate was similar for these 2 days with a value of $1.3-1.4 \mu \mathrm{g} \mathrm{m}^{-3}$, but the concentration of fine mode nitrate was about 4 times higher on 24 May $\left(0.18 \mu \mathrm{g} \mathrm{m}^{-3}\right)$ than that on 7 June $\left(0.04 \mu \mathrm{g} \mathrm{m}^{-3}\right)$, further suggesting that the relative lower humidity favors the particle-phase nitrate over chloride.

\subsection{The effects of long-range transport and in situ chemistry}

There were 4 days during which the amounts and properties of the aerosols were significantly impacted by long-range transport and unique formation and alteration mechanisms: one in each GZ and ZH (both occurring on 12 June) and three in $\operatorname{JFM}(1,3$, and 5 June). 

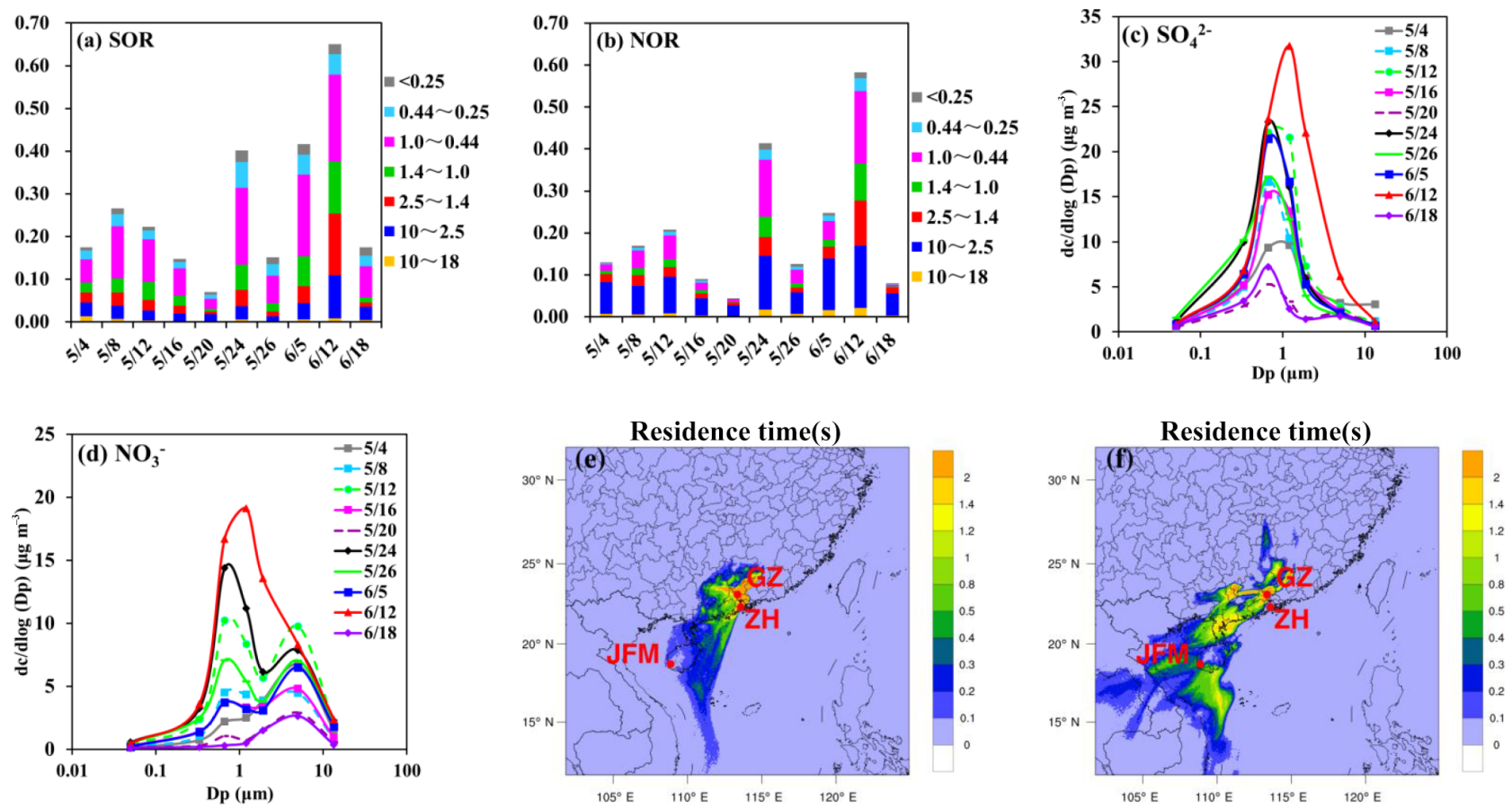

Figure 6. Case study on 12 June in GZ. (a-b) The time series of sulfur oxidation ratio (SOR) and nitrogen oxidation ratio (NOR). (c-d) The mass size distribution of $\mathrm{SO}_{4}^{2-}$ and $\mathrm{NO}_{3}^{-}$. (e-f) FLEXPART-WRF total column residence times over the last $72 \mathrm{~h}$, arriving in GZ on 12 June at 100 and $1000 \mathrm{~m}$.

On 12 June in both $\mathrm{GZ}$ and $\mathrm{ZH}$, firstly, the total aerosol concentration was the highest measured, at 93.7 and $35.1 \mu \mathrm{g} \mathrm{m}^{3}$ in GZ and ZH, respectively (Fig. 2). Secondly, the concentration of secondary soluble ions was the highest measured. The sulfur oxidation ratio (SOR) and nitrogen oxidation ratio (NOR) are applied to indicate the degree of oxidation of $\mathrm{SO}_{2}$ and $\mathrm{NO}_{2}$ precursor gases (Wang et al., 2005). The equations for SOR and NOR are calculated as $\mathrm{SOR}=n-\mathrm{SO}_{4}^{2-} /\left(n-\mathrm{SO}_{4}^{2-}+n-\mathrm{SO}_{2}\right)$ and $\mathrm{NOR}=$ $n-\mathrm{NO}_{3}^{-} /\left(n-\mathrm{NO}_{3}^{-}+n-\mathrm{NO}_{2},\right)$, where $n-\mathrm{SO}_{4}^{2-}$ and $n-\mathrm{NO}_{3}^{-}$ are the molar concentrations of particulate $\mathrm{SO}_{4}^{2-}$ and $\mathrm{NO}_{3}^{-}$ and $n-\mathrm{SO}_{2}$ and $n-\mathrm{NO}_{2}$ are the molar concentrations of the precursor gases $\mathrm{SO}_{2}$ and $\mathrm{NO}_{2}$. SOR and NOR was also the highest on 12 June at a range of $0.44-1.0 \mu \mathrm{m}$ in GZ with values of 0.20 and 0.17 , respectively (Fig. 6a-b; no supported data to estimate SOR and NOR in ZH on this day). Thirdly, this was the only day in GZ that the nitrate size distribution was found to be unimodal and peaked in the $1.0-1.44 \mu \mathrm{m}$ size range (Fig. 6d), which was the largest of any mean size nitrate in GZ measured. Meanwhile, the nitrate size distribution changed from coarse mode to bimodal and peaked in 0.25 $0.44 \mu \mathrm{m}$ size range in $\mathrm{ZH}$ measured on this day (Fig. S1j in the Supplement). Fourthly, the peak of sulfate and ammonia shifted from typical values in the $0.44-1.0 \mu \mathrm{m}$ size range to the $1.0-1.44 \mu \mathrm{m}$ size range (take GZ, for example; Figs. 6c and S1f). All of these are consistent with enhanced secondary production. Such a statistically enhanced amount of secondary production requires the aerosols to have had considerably more time in the atmosphere to have aged as they have and therefore is consistent with them having undergone considerable long-range transport (Cohen et al., 2011).

To provide further evidence, 3-day air mass backward trajectories were conducted at each of the three sites. The parcels were released at initial heights of 100, 500, 1000 and $2000 \mathrm{~m}$, hourly, as a means of robustly sampling the boundary layer throughout the day. The results showed that air masses winded up over GZ and ZH in the lower free troposphere or near the top of the boundary layer had mostly originated over continental Southeast Asia, while those winding up near the surface had mostly come from northern China (take GZ, for example; Fig. S1a). Furthermore, since the air masses came from opposite directions at nearly the same time, the end result was observed to be a stable meteorological condition over GZ (very low wind $0.1 \mathrm{~m} \mathrm{~s}^{-1}$ ) and $\mathrm{ZH}$ (wind speed was $1 \mathrm{~m} \mathrm{~s}^{-1}$, which was the lowest during the sampling times). In fact, it seems from the back trajectory analysis that there was descending air in and around GZ and ZH on this day, which implies that air transported from far away in the lower free troposphere would have been transported back near the surface (take GZ, for example; Fig. S1b-c). FLEXPART-WRF was next applied to address the issue of the air residence time through the column over GZ and ZH for that day. As can be shown in Fig. 6e-f, there was a strong influence from the local region of GZ and surrounding adjoining cities, at a lower altitude $(500 \mathrm{~m}$ and 

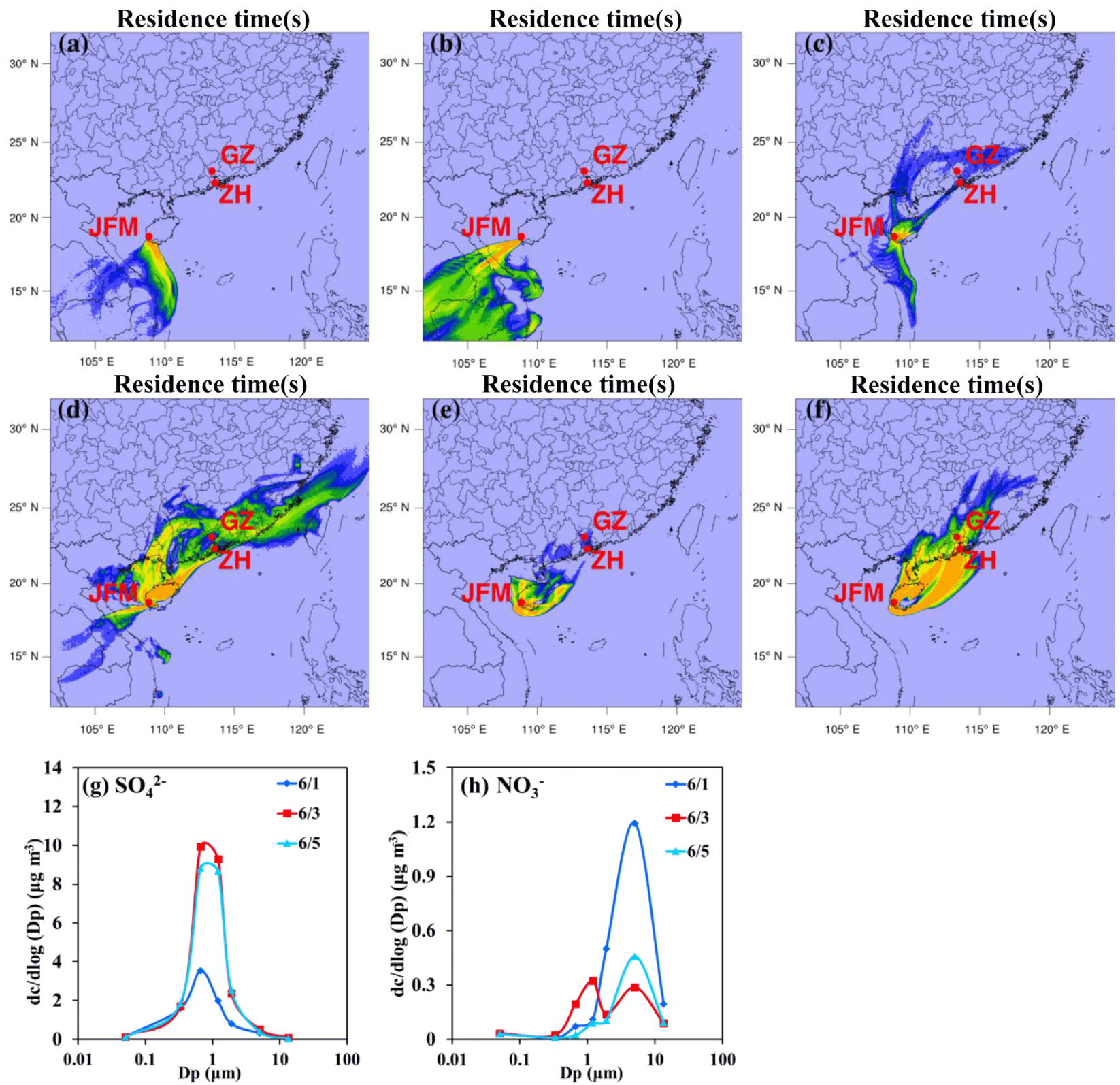

Figure 7. Case study on 1, 3, and 5 June in JFM. (a-b) FLEXPART-WRF total column residence times over the last $72 \mathrm{~h}$, arriving in JFM on 1 June at 100 and $1000 \mathrm{~m}$. (c-d and $\mathbf{e}-\mathbf{f})$ Same as (a-b) but on 3 and 5 June, respectively. (g-h) The mass size distribution of $\mathrm{SO}_{4}^{2-}$ and $\mathrm{NO}_{3}^{-}$. The colorbar for (a)-(f) is the same as that for Fig. 6e-f.

lower; Figs. 6e and S1d-e). All of these results were further consistent with the high levels of aerosols measured as well as additional secondary processing having had time to occur.

Except for in situ formation, long-range transport was another impact factor. First, HYSPLIT (GZ, for example, in Fig. S1a) and FLEXPART-WRF (Fig. 6f) showed that the air flow was mostly from Southeast Asia at levels over the boundary layer (Fig. 6f) and hence had undergone long-range transport. Second, the wind speed near the surface suddenly became very low. Therefore, there had been a rapid change in the wind speed. Based on conservation laws for air mass, it would be excepted for there to be some reasonable amount of mixing of the air vertically. This was consistent with the finding that some of the air which had undergone long-range transport would have mixed into the surface region. Furthermore, the ratio of $\mathrm{OC}$ to $\mathrm{EC}$ concentrations was the minimum measured values on 12 June, with a mean ratio of 1.32 and 2.39 in GZ and ZH, respectively. Also, OC showed a bimodal distribution, although predominantly in the fine mode, while EC mostly peaked at fine mode particles (GZ, for example, in 

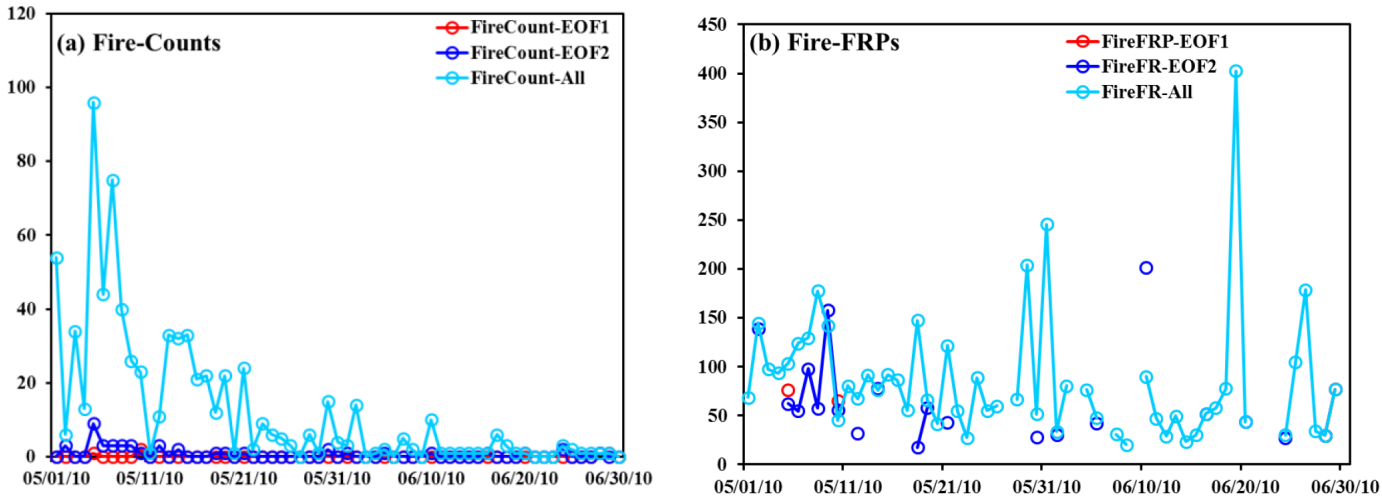

Figure 8. Spatially averaged/aggregated statistics of (a) MODIS fire numbers (count) and (b) fire radiative power (FRP) over Southeast Asia for May and June 2010. The statistics represent the respective count (total number of burning $1 \mathrm{~km} \times 1 \mathrm{~km}$ pixels) and average FRP [W m ${ }^{-2}$ per $1 \mathrm{~km} \times 1 \mathrm{~km}$ pixel] over the whole of Southeast Asia and the specific regions where the AOD (as an indicator for smoke) has its highest levels of variability: EOF1 and EOF2.

(a) Mean AOD

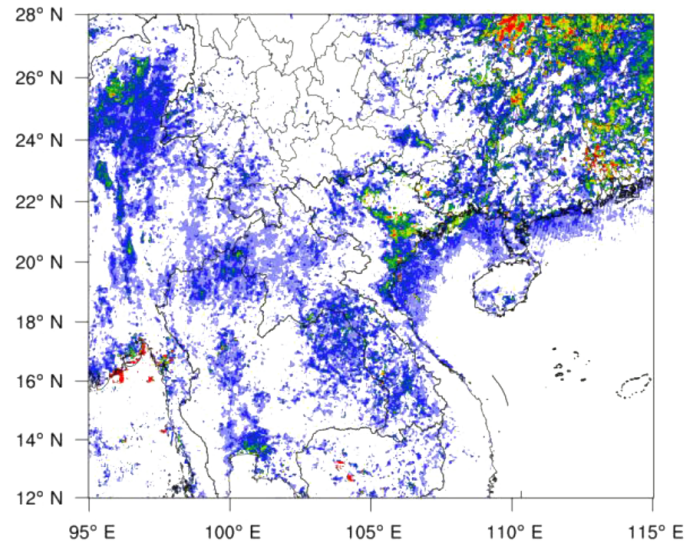

(b) SD AOD

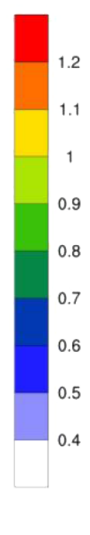

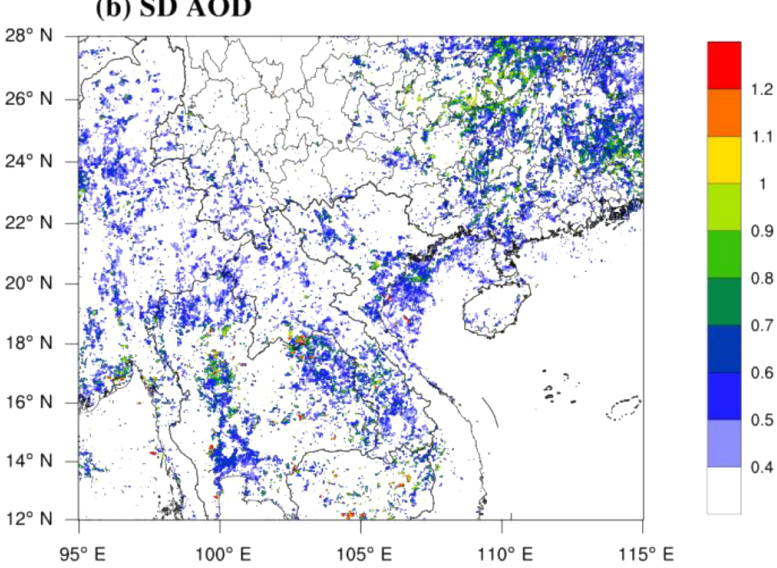

Figure 9. Average spatial distribution of the (a) mean and (b) standard deviation of daily MODIS AOD from 1 May through 30 June 2010.

Fig. S1g-h), indicating that the organic aerosol was mostly primary, as would be expected from large fire sources. Additionally, the $\mathrm{K}^{+}$concentration on 12 June was about 2-3 times higher than that of the mean value measured in $\mathrm{GZ}$ and ZH (GZ, for example, in Figs. 10a-b and S1). $\mathrm{Na}^{+}$and $\mathrm{Cl}^{-}$ size distributions were found to be unimodal distributions in GZ, where they peaked in the $1.0-1.44 \mu \mathrm{m}$ size range. $\mathrm{Na}^{+}$ and $\mathrm{Cl}^{-}$were bimodal distribution in $\mathrm{ZH}$ on 12 June (figures not showed here). All of these findings above, including the time of the year and the location, are consistent with the long-range transported biomass burning from Southeast Asia (Cohen, 2014).

At JFM the total aerosol concentration was highest on the 1,3 , and 5 June. In particular, the levels of EC and potassium were elevated on all 3 days, and the ratio of OC to EC was depressed (Fig. S2c-e). However, in addition to these clues, there were some differences: the levels of sulfate and ammonia were remarkably elevated on 3 and 5 June (Figs. $7 \mathrm{~g}$ and S2b), likely due to a mixing of urban sources with the fire sources. In contrast, on 1 June the sulfate was lower, but the nitrate was considerably higher, peaking in the coarse mode (Fig. 7h), likely due to mixing of South China Sea air with the fire sources.

HYSPLIT results showed that on all three of these days, the great majority of air masses arriving at JFM originated from continental Southeast Asia (Fig. S2a). However, all of these parcels of air arrived in the upper boundary layer or the lower free troposphere. By analyzing the FLEXPART-WRF runs at higher resolution, it was demonstrated that there was a strong influence of air from ocean on 1 June (Fig. 7a-b) at the lower parts of the boundary layer. This is consistent with the observed non-elevated sulfate and elevated coarse nitrate on that day. Furthermore, the FLEXPART-WRF runs at higher resolution and demonstrated a considerable influence of air from southern China (urban and semi-urban Guangdong Province, including many major shipping lanes) on 3 and 5 June, again in the lower parts of the boundary layer (Fig. 7c-f). This is again consistent with the observed ele- 

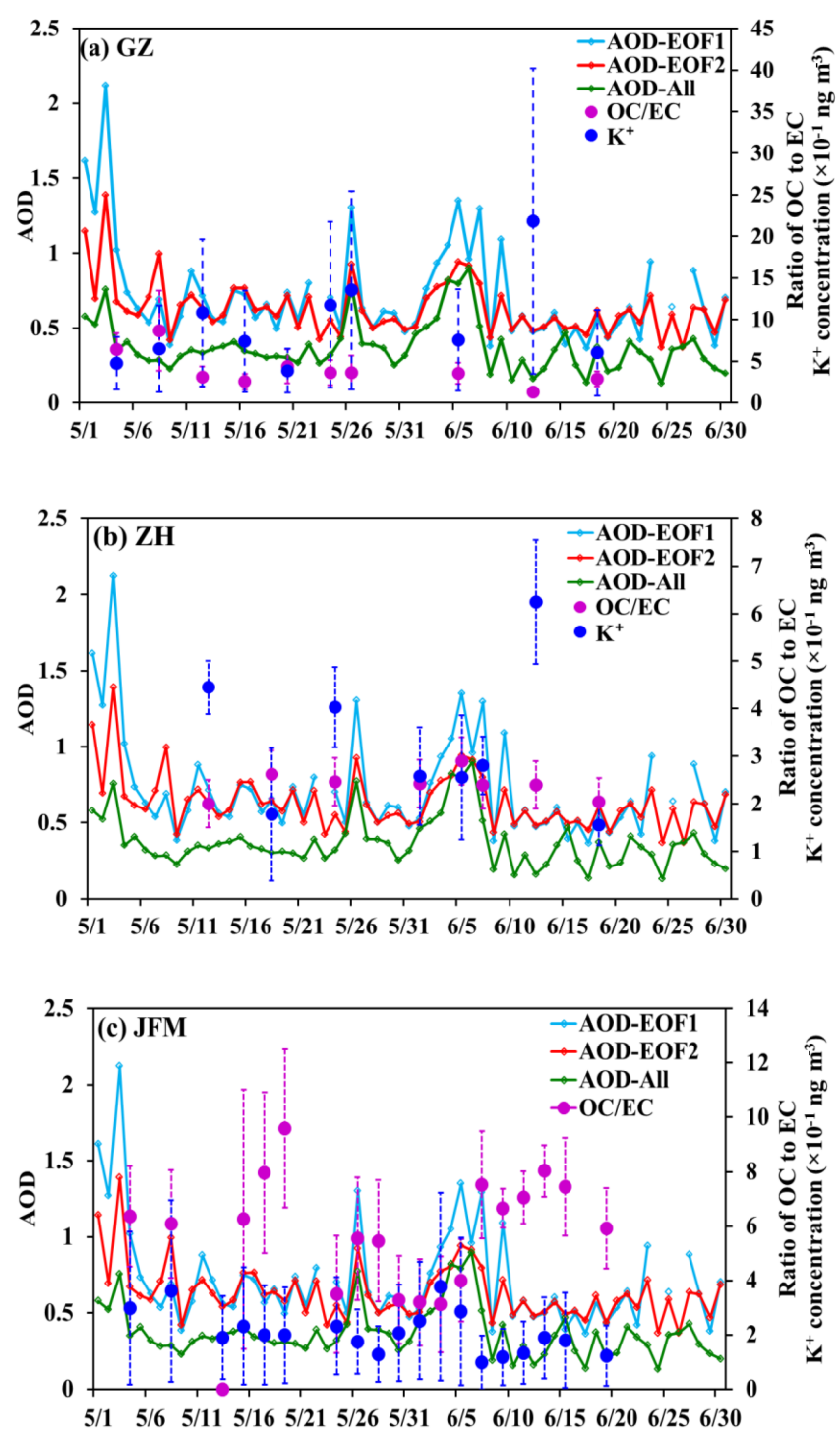

Figure 10. The time-varying statistics of the AOD averaged over the first two EOFs of the AOD (reflecting the regions most impacted by AOD variance or smoke from fires) and the average $\mathrm{K}^{+}$concentration and average ratio of $\mathrm{OC} / \mathrm{EC}$ in the three sites.

vated levels of sulfate due to the in situ processing of urban emissions as the air was transported to JFM and then mixed with the fire emissions transported from the other direction at height. Additionally, there was some amount of fine mode nitrate found on 3 June, further consistent with the in situ processing of $\mathrm{NO}_{2}$ emitted along with biomass combustion, and therefore further evidence that mixing occurred between the two different source regions.

\subsection{Quantifying the impacts of fires}

Taking a first look at the possibility that fires are responsible, as described above, we look at a summary of the statistics of the MODIS fire hotspots (Fig. 8). As we observe, while the total number of fire hotspots occurring throughout Southeast Asia is moderate in early May, the number reduces to the extent that there are effectively almost no burning parcels. Furthermore, those few square kilometers that are burning are of low radiative intensity, under $200 \mathrm{~W} \mathrm{~m}^{-2}$, and hence only moderately or lowly emitting, with the exception of a single day in late June, after the period of interest has ended. This result showed that the MODIS fire hotspots are not very useful in wet and tropical regions. Since MODIS fire hotspots are obstructed by both clouds and high levels of aerosols in the atmosphere, both of which are found associated with tropical forest fires. Additionally, due to the highly wet ground surface, a significant number of the fires with low temperature are therefore not observed using the MODIS sensors (Cohen, 2014; Giglio et al., 2006; Yu et al., 2015).

Instead, we follow the approach of Cohen (2014) and look at the once to twice daily measured AOD data (Fig. 9) in the context of the empirical orthogonal function (EOF) approach. MODIS fire hotspots are effectively point measurements and as such are not spatially robust, while AOD is continuous and easier to observe and provides more precise and robust spatial information (Morisette et al., 2005a, b; Levy et al., 2007, 2010; Remer et al., 2005). Therefore, if a significant signal exists, it is far easier to track and transport at the scale of the inverse meteorological methods used here. The rationale is that over Southeast Asia there are only a few known large urban centers (Hanoi, Ho Chi Minh City, and Bangkok). Therefore, any other significant contribution to the variance of measured AOD must be from fires. The EOF technique has been shown to be an optimal manner by which to reproduce both the spatial extent and magnitude of the smoke over continental Southeast Asia (Cohen, 2014; Cohen and Leocure, 2015).

As observed, the major regions of high AOD (average AOD $>0.4$ ) are found over Southeast Asia as described above, with most of the sources coming from fires found in two arcs: one from eastern Thailand, through Laos, and ending in central Vietnam; and the other in the forests of Myanmar. The region around Hanoi is hard to decipher, as it could be an urban expansion or fire. Additionally, there are regions found in urban East Asia, including the region between Hong Kong and Guangzhou and urbanization along the Yangtze River; however, all of these are known regions of urbanization and are not regions where fire is important.

An EOF analysis concludes that in fact these are the only two statistically significant EOFs (Fig. 10). The measured AOD over both of these regions is clearly elevated compared with the region as a whole throughout the entire time. Furthermore, there is an especially large contribution from these two EOFs compared with the background over Southeast Asia only (excluding AOD measured over China, which is downwind and hence not a fire source region) from 31 May to 6 June. Given the rapid transport time from Southeast Asia to JFM, the fact that these peaks occur within 1 day of the peaks in the fires is reasonable. Additionally, while the over- 
all Southeast Asian AOD drops from 9 June onwards, there is a very significant difference (difference in AOD more than 0.5 ) between the overall AOD and that over the two source regions again from 8 to 13 June. Given that there are markers of fires in $\mathrm{GZ}$ and $\mathrm{ZH}$ on 12 June, including high potassium and a low OC / EC ratio, and that a significant portion of the airflow over these regions originated from Southeast Asia within the past $72 \mathrm{~h}$, these results are consistent with high fires originating from Southeast Asia, then being transported over the next $72 \mathrm{~h}$ to $\mathrm{GZ}$ and $\mathrm{ZH}$. The fact that only 1 day has such measured conditions at the surface is likely due to the fact that the smoke is mostly concentrated near the boundary layer and hence local vertical mixing was most prevalent on or around 12 June.

\section{Conclusions}

Aerosol samples were collected at three sites using a sixstage sampler during the local wet season in southern China (May-June) in 2010 to jointly study the mass and size distributions of aerosol chemical components. These site observations, together with model simulations and remote-sensing data, were used to investigate impacts of chemistry and atmospheric transport on the aerosol formation mechanisms at the three sites over southern China. These were chosen such that they spanned different source and meteorological regions, at urban site GZ, suburban site $\mathrm{ZH}$, and a remote and forested site at JFM.

Sulfate and ammonium were found to have a single peaked distribution from 0.44 to $1.0 \mu \mathrm{m}$ at all sites over the entire sampling period in this study and accounted for 57.5-99\% of the daily-average total aerosol mass. Aqueous-phase reactions were found to be an essential factor to the formation of droplet sulfate. In addition, we found significant secondary processing and enhancement due to meteorological drivers which were wetter or allowed for a longer residence time.

A bimodal distribution was found for nitrate, with a droplet mode in $0.44-1.0 \mu \mathrm{m}$, indicating that it was formed under heavily polluted conditions or through similar secondary aerosol processing. In contrast, nitrate had a significant fraction in the coarse mode in $\mathrm{ZH}$ and JFM during the wet season, where it accounted for about $40 \%$ of total mass. In this case, we found that the mass size distribution of nitrate was likely attributed to chloride depletion, with almost complete chloride depletion found in $\mathrm{ZH}$ and JFM during the wet season. Additionally, relative humidity was an important consideration in chloride depletion under relatively lower relative humidity conditions, leading to the increase of coarse mode nitrate.

OC and EC showed a broad peak at $0.25-1.0 \mu \mathrm{m}$ in GZ and $\mathrm{ZH}$, consistent with significant local sources, from urbanization, transport, residential, and shipping sources. Furthermore, under less heavily polluted conditions, OC was found to have a bimodal distribution in JFM, with important contri- butions from secondary particle formation in the fine mode and potential biological aerosol in the coarse mode particles.

Additionally, OC and EC were shown to have broad peaks and a significantly different ratio, raising the likelihood of a mixing of the local emissions with emissions transported long range from biomass burning in Southeast Asia. These conditions were further supported by a large amount of potassium found jointly with the aerosol. An in-depth analysis of the meteorology and remotely sensed fire and AOD properties, in conjunction with a variance maximizing technique, provided further evidence to help us validate this assumption. It is clear that there was a significant impact on GZ and $\mathrm{ZH}$ from fire sources from Thailand, Laos, and Vietnam, as well as possible long-range transport of urban emissions from the urban megacity of Hanoi in Vietnam. The combination of local formation and long-range transport played a significant role on the variation of particle chemical compositions.

Overall, we found that the size distribution and formation of aerosols greatly depend on emissions, location, and in situ processing, especially aqueous-phase reactions. Strong local formation and long-range transport of both urban pollution from GZ and of biomass burning from Southeast Asia all were observed to influence the size distribution of chemical components across all of the area studies. However, the interaction between sea salt aerosols and anthropogenic pollutants showed significant effects at coastal locations and play an important role in the deterioration of the air quality in southern China under high relative humidity conditions during the wet season.

\section{Data availability}

Please refer to the Supplement for the mass size distribution data of chemical components at the three sites.

\section{The Supplement related to this article is available online at doi:10.5194/acp-16-13271-2016-supplement.}

Acknowledgements. This work was supported by National Science Fund for Outstanding Young Scholars (41425020), China Special Fund for Meteorological Research in the Public Interest (GYHY201406031), National Science \& Technology Pillar Program (2014BAC21B02),k and Specialized Research Fund for the Doctoral Program of Higher Education in China (2013380004115009). The authors would especially like to thank Guenter Engling at National Tsing Hua University for helping to chemical analysis at the laboratory.

Edited by: J. Huang

Reviewed by: two anonymous referees 


\section{References}

Anlauf, K., Li, S. M., Leaitch, R., Brook, J., Hayden, K., Toom-Sauntry D., and Wiebe, A.: Ionic composition and size characteristics of particles in the Lower Fraser Valley: Pacific 2001 field study, Atmos. Environ., 40, 2662-2675, doi:10.1016/j.atmosenv.2005.12.027, 2006.

Barth, M. C., Hegg, D. A., and Hobbs, P. V.: Numerical modeling of cloud and precipitation chemistry associated with two rainbands and some comparisons with observations, J. Geophys. Res., 97, 5825-5845, doi:10.1029/92JD00464, 1992.

Brioude, J., Arnold, D., Stohl, A., Cassiani, M., Morton, D., Seibert, P., Angevine, W., Evan, S., Dingwell, A., Fast, J. D., Easter, R. C., Pisso, I., Burkhart, J., and Wotawa, G.: The Lagrangian particle dispersion model FLEXPART-WRF version 3.1, Geosci. Model Dev., 6, 1889-1904, doi:10.5194/gmd-61889-2013, 2013.

Burnett, R. T., Pope III, C. A., Ezzati, M., Olives, C., Lim, S. S., Mehta, S., Shin, H. H., Singh, G. S., Hubbell, B., Brauer, M., Anderson, H. R., Smith, K. R., Balmes, J. R., Bruce, N. G., Kan, H. D., Laden, F., Prüss-Ustün, A., Turner, M. C., Gapstur, S. M., Diver, W. R., and Cohen, A.: An integrated risk function for estimating the global burden of disease attributable to ambient fine particulate matter exposure, Environ. Health Persp., 122, 397403, doi:10.1289/ehp.1307049, 2014.

Cao, J. J., Lee, S. C., Ho, K. F., Zou, S. C., Fung, K., Li, Y., Watson, J. G., and Chow, J. C.: Spatial and seasonal variations of atmospheric organic carbon and elemental carbon in Pearl River Delta Region, China, Atmos. Environ., 38, 4447-4456, doi:10.1016/j.atmosenv.2004.05.016, 2004.

Chatterjee, A., Adak, A., Singh, A. K., Srivastava, M. K., Ghosh, S. K., Tiwari, S., Devara, P. C. S., and Raha, S.: Aerosol chemistry over a high altitude station at northeastern Himalayas, India, PLoS ONE, 5, e11122, doi:10.1371/journal.pone.0011122, 2010.

Chen, H. Z., Wu, D., Liao, B. T., Mao, X., Zhuang, H. B., Li, L., Liu, A. M., Li, H. Y., and Li, F.: Influence of different acidic gases and relative humidity on the chlorine loss of marine aerosols, Acta Scientiae Circustantiae, 33, 1141-1149, 2013b (in Chinese with English Abstract).

Chen, S. Y., Huang, J. P., Zhao, C., Qian, Y., Leung, L. R., and Yang, B.: Modeling the transport and radiative forcing of Taklimakan dust over the Tibetan Plateau: A case study in the summer of 2006, J. Geophys. Res., 118, 797-812, doi:10.1002/jgrd.50122, $2013 a$

Clegg, S.L., Brimblecombe, P., and Wexler, A.S.: Thermodynamic Model of the System $\mathrm{H}^{+}-\mathrm{NH}_{4}^{+}-\mathrm{SO}_{4}^{2-}-\mathrm{NO}_{3}^{-}-\mathrm{H}_{2} \mathrm{O}$ at Tropospheric Temperatures, J. Phys. Chem. A, 102, 2137-2154, doi:10.1021/jp973042r, 1998.

Cohen, J. B.: Quantifying the Occurrence and Magnitude of the Southeast Asian Fire Climatology, Environ. Res. Lett., 9, 114018, doi:10.1088/1748-9326/9/11/114018, 2014.

Cohen, J. B. and Lecoeur, E.: Decadal-scale relationship between measurements of aerosols, land-use change, and fire over Southeast Asia, Atmos. Chem. Phys. Discuss., 15, 26895-26957, doi:10.5194/acpd-15-26895-2015, 2015.

Cohen, J. B. and Prinn, R. G.: Development of a fast, urban chemistry metamodel for inclusion in global models, Atmos. Chem. Phys., 11, 7629-7656, doi:10.5194/acp-11-7629-2011, 2011.
Cohen, J. B. and Wang, C.: An Estimate of Global Black Carbon Emissions Using a Top-Down Kalman Filter Approach, J. Geophys. Res., 119, 1-17, doi:10.1002/2013JD019912, 2013.

Cohen, J. B., Prinn, R.G., and Wang, C.: The Impact of detailed urban-scale processing on the composition, distribution, and radiative forcing of anthropogenic aerosols, Geophys. Res. Lett., 38, L10808, doi:10.1029/2011GL047417, 2011.

Chung S. H. and Seinfeld, J. H.: Climate response of direct radiative forcing of anthropogenic black carbon, J. Geophys. Res., 110, D11102, doi:10.1029/2004JD005441, 2005.

Dasgupta, P. K., Campbell, S. W., Al-Horr, R. S., Ullah, S. M. R., Li, J. Z., Amalfitano, C., and Poor, N. D.: Conversion of sea salt aerosol to $\mathrm{NaNO}_{3}$ and the production of $\mathrm{HCl}$ : Analysis of temporal behavior of aerosol chloride/nitrate and gaseous $\mathrm{HCl} / \mathrm{HNO}_{3}$ concentrations with AIM, Atmos. Environ., 41, 4242-4257, doi:10.1016/j.atmosenv.2006.09.054, 2007.

Delene, D. J. and Ogren, J. A.: Variability of aerosol optical properties at four North American surface monitoring sites, J. Atmos. Sci., 59, 1135-1150, 2002.

Draxler, R. R. and Hess, G. D.: An overview of the HYSPLIT_4 modeling system of trajectories, dispersion, and deposition, Aust. Meteorol. Mag., 47, 295-308, 1998.

Dubovik, O., Smirnov, A., Holben, B. N., King, M. D., Kaufman, Y. J., Eck, T. F., and Slutsker, I.: Accuracy assessments of aerosol optical properties retrieved from Aerosol Robotic Network (AERONET) Sun and sky radiance measurements, J. Geophys. Res., 105, 9791-9806, doi:10.1029/2000JD900040, 2000.

Ervens, B., Turpin, B. J., and Weber, R. J.: Secondary organic aerosol formation in cloud droplets and aqueous particles (aqSOA): a review of laboratory, field and model studies, Atmos. Chem. Phys., 11, 11069-11102, doi:10.5194/acp-1111069-2011, 2011.

Grell, G. A., Peckham, S. E., Schmitz, R., McKeen, S. A., Frost, G., Skamarock, W. C., and Eder. B.: Fully coupled "online" chemistry in the WRF model, Atmos. Environ., 39, 6957-6976, doi:10.1016/j.atmosenv.2005.04.027, 2005.

Giglio, L., Kendall, J. D., and Mack, R.: A multi-year active fire data set for the tropics derived from the TRMM VIRS, Int. J. Remote Sens., 24, 4505-4525, doi:10.1080/0143116031000070283, 2003.

Giglio, L., Csiszar, I., and Justice, C.O.: Global distribution and seasonality of active fires as observed with the Terra and Aqua Moderate Resolution Imaging Spectroradiometer (MODIS) sensors, J. Geophys. Res., 111, G02016, doi:10.1029/2005JG000142, 2006.

Han, Y., Han, Z., Cao, J. J., Chow, J. C., Watson, J. G., An, Z. S., Liu, S. X., and Zhang, R. J.: Distribution and origin of carbonaceous aerosol over a rural high-mountain lake area, Northern China and its transport significance, Atmos. Environ., 42, 24052414, doi:10.1016/j.atmosenv.2007.12.020, 2008.

Harrison, R. M. and Pio, C. A.: Size differentiated composition of inorganic atmospheric aerosols of both marine and polluted continental origin, Atmos. Environ., 17, 1733-1738, doi:10.1016/0004-6981(83)90180-4, 1983.

Heald, C. L. and Spracklen, D. V.: Atmospheric budget of primary biological aerosol particles from fungal spores, Geophys. Res. Lett., 36, L09806, doi:10.1029/2009GL037493, 2009.

Huang, J. P., Wang, T. H., Wang, W. C., Li, Z. Q., and Yan, H. R.: Climate effects of dust aerosols over East Asian arid 
and semiarid regions, J. Geophys. Res., 119, 11398-11416, doi:10.1002/2014JD021796, 2014.

Huang, X. F., Yu, J. Z., He, L. Y., and Hu, M.,: Size distribution characteristics of elemental carbon emitted from Chinese vehicles: results of a tunnel study and atmospheric implications, Environ. Sci. Technol., 44, 5355-5360, doi:10.1021/es0607281, 2006.

Huang, Z. E., Harrision, R. M., Allen, A. G., James, J. D., Tilling, R. M., and Yin, J. X.: Field intercomparison of filter pack and impactor sampling for aerosol nitrate, ammonium, and sulphate at coastal and inland sites, Atmos. Res., 71, 215-232, doi:10.1016/j.atmosres.2004.05.002, 2004.

Hsu, S. C., Liu, S. C., Kao, S. J., Jeng, W. L., Huang, Y. T., Tseng, C. M., Tsai, F. J., Tu, J. Y., and Yang, Y.: Water-soluble species in the marine aerosol from the northern South China Sea: High chloride depletion related to air pollution, J. Geophys. Res., 112, D19304, doi:10.1029/2007JD008844,2007.

Jacobson, M. Z.: Global direct radiative forcing due to multicomponent anthropogenic and natural aerosols, J. Geophys. Res., 106, 1551-156, doi:10.1029/2000JD900514, 2001.

Kim, S.-W., Berthier, S., Raut, J.-C., Chazette, P., Dulac, F., and Yoon, S.-C.: Validation of aerosol and cloud layer structures from the space-borne lidar CALIOP using a ground-based lidar in Seoul, Korea, Atmos. Chem. Phys., 8, 3705-3720, doi:10.5194/acp-8-3705-2008, 2008.

Lan, Z. J., Chen, D. L., Li, X., Huang, X. F., He, L. Y., Deng, Y. G., Feng, N., and Hu, M.: Modal characteristics of carbonaceous aerosol size distribution in an urban atmosphere of South China, Atmos. Res., 100, 51-60, doi:10.1016/j.atmosres.2010.12.022, 2011.

Levy, R., Remer, L., and Dubovik, O.: Global aerosol optical properties and application to Moderate Resolution Imaging Spectroradiometer aerosol retrieval over land, J. Geophys. Res., 112, 115, doi:10.1029/2006JD007815, 2007.

Levy, R. C., Remer, L. A., Kleidman, R. G., Mattoo, S., Ichoku, C., Kahn, R., and Eck, T. F.: Global evaluation of the Collection 5 MODIS dark-target aerosol products over land, Atmos. Chem. Phys., 10, 10399-10420, doi:10.5194/acp-10-10399-2010, 2010.

Lim, Y. B., Tan, Y., Perri, M. J., Seitzinger, S. P., and Turpin, B. J.: Aqueous chemistry and its role in secondary organic aerosol (SOA) formation, Atmos. Chem. Phys., 10, 1052110539, doi:10.5194/acp-10-10521-2010, 2010.

Liu, S., Hu, M., Slanina, S., He, L. Y., Niu, Y. W., Bruegemann, E., Gnauk, T., and Herrmann, H.: Size distribution and source analysis of ionic compositions of aerosols in polluted periods at Xinken in Pearl River Delta (PRD) of China, Atmos. Environ., 42, 6284-6295, doi:10.1016/j.atmosenv.2007.12.035, 2008.

Liu, Y., Huang, J., Shi, G., Takamura, T., Khatri, P., Bi, J., Shi, J., Wang, T., Wang, X., and Zhang, B.: Aerosol optical properties and radiative effect determined from sky-radiometer over Loess Plateau of Northwest China, Atmos. Chem. Phys., 11, 1145511463, doi:10.5194/acp-11-11455-2011, 2011.

Lu, Q., Zheng, J. Y., Ye, S. Q., Shen, X. L., Yuan, Z. B., and Yin, S. S.: Emission trends and source characteristics of $\mathrm{SO}_{2}, \mathrm{NOx}, \mathrm{PM}_{10}$ and VOCs in the Pearl River Delta region from 2000 to 2009, Atmos. Environ., 76, 11-20, doi:10.1016/j.atmosenv.2012.10.062, 2013.
Meng, Z. and Seinfeld, J. H.: On the source of the submicrometer droplet mode of urban and regional aerosols, Aerosol Sci. Technol., 20, 253-265, doi:10.1080/02786829408959681, 1994.

Myhre, G., Samset, B. H., Schulz, M., Balkanski, Y., Bauer, S., Berntsen, T. K., Bian, H., Bellouin, N., Chin, M., Diehl, T., Easter, R. C., Feichter, J., Ghan, S. J., Hauglustaine, D., Iversen, T., Kinne, S., Kirkevåg, A., Lamarque, J.-F., Lin, G., Liu, X., Lund, M. T., Luo, G., Ma, X., van Noije, T., Penner, J. E., Rasch, P. J., Ruiz, A., Seland, Ø., Skeie, R. B., Stier, P., Takemura, T., Tsigaridis, K., Wang, P., Wang, Z., Xu, L., Yu, H., Yu, F., Yoon, J.-H., Zhang, K., Zhang, H., and Zhou, C.: Radiative forcing of the direct aerosol effect from AeroCom Phase II simulations, Atmos. Chem. Phys., 13, 1853-1877, doi:10.5194/acp-13-18532013, 2013.

Morisette, J. T., Giglio, L., Csiszar, I., and Justice, C. O.: Validation of the MODIS active fire product over Southern Africa with ASTER data, Int. J. Remote Sens., 26, 4239-4264, doi:10.1080/01431160500113526, 2005a.

Morisette, J. T., Giglio, L., Csiszar, I., Setzer, A., Schroeder, W., Morton, D., and Justice, C. O.: Validation of MODIS active fire dectection productes derived from two algorithms, Earth Interact., 9, 1-23, doi:10.1175/EI141.1, 2005b.

Petrenko, M., Kahn, R., Chin, M., Soja, A., Kucsera, T., and Harshvardhan, T. K.: The use of satellite-measured aerosol optical depth to constrain biomass burning emissions source strength in the global model GOCART, J. Geophys. Res., 117, D18212, doi:10.1029/2012JD017870, 2012.

Pierson, W. R. and Brachaczek, W. W.: Coarse and fine particle atmospheric nitrate and $\mathrm{HNO}_{3}(\mathrm{~g})$ in Claremont, California, during the 1985 nitrogen species methods comparison study, Atmos. Environ., 22, 1665-1668, doi:10.1016/0004-6981(88)90394-0, 1998.

Pillai, P. S. and Moorthy, K. K.: Aerosol mass-size distributions at a tropical suburban environment: response to mesoscale and synoptic processes, Atmos. Environ., 35, 4099-4112, doi:10.1016/S1352-2310(01)00211-4, 2001.

Pio, C., Legrand, M., Oliveira, T., Afonso, J., Santos, C., Caseiro, A., Fialho, P., Barata, F., Puxbaum, H., Sanchez-Ochoa, A., Kasper-Giebl, A., Gelencsér, A., Preunkert, S., and Schock, M.: Climatology of aerosol composition (organic versus inorganic) at nonurban sites on a west-east transect across Europe, J. Geophys. Res.-Atmos., 112, D23S02, doi:10.1029/2006JD008038, 2007.

Ramanathan, V. and Garmichael, G.: Global and regional climate changes due to black carbon, Nat. Geosci., 1, 221-227, doi:10.1038/ngeo156, 2008.

Remer, L., Kaufman, Y., Tanre, D., Mattoo, S., Chu, D. A., Martins, J. V., Li, R. R., Ichoku, C., Levy, R. C., Kleidman, R. G., Eck, T. F, Vermote, E., and Holben, B. N.: The MODIS Aerosol Algorithms, Products, and Validation, J. Atmos. Sci., 62, 947-973, doi:10.1175/JAS3385.1, 2005.

Remer, L. A., Mattoo, S., Levy, R. C., and Munchak, L. A.: MODIS $3 \mathrm{~km}$ aerosol product: algorithm and global perspective, Atmos. Meas. Tech., 6, 1829-1844, doi:10.5194/amt-6-1829-2013, 2013.

Rosenfeld, D., Sherwood, S., Wood, R., and Donner, L.: Climate effects of aerosol- cloud interactions, Science, 343, 379-380, doi:10.1126/science.1247490, 2014. 
Schuster, G. L., Dubovik, O., and Holben, B. N.: Angstrom exponent and bimodal aerosol size distributions, J. Geophys. Res., 111, D07207, doi:10.1029/2005JD006328, 2006.

Seinfeld, J. and Pandis, S.: Atmospheric Chemistry and Physics: From Air Pollution to Climate Change, John Wiley \& Sons, New York, 2006.

Situ, S., Guenther, A., Wang, X., Jiang, X., Turnipseed, A., Wu, Z., Bai, J., and Wang, X.: Impacts of seasonal and regional variability in biogenic VOC emissions on surface ozone in the Pearl River delta region, China, Atmos. Chem. Phys., 13, 1180311817, doi:10.5194/acp-13-11803-2013, 2013.

Skamarock, W. C., Klemp, J. B., Dudhia, J., Gill, D. O., Barker, D. M., Duda, M. G., Huang, X. Y., Wang, W., and Powers, J. G.: A Description of the Advanced Research WRF Version 3, NCAR Tech. Note NCAR/TN-475+STR, 113, doi:10.5065/D68S4MVH, 2008.

Stelson, A. W. and Seinfeld, J. H.: Relative humidity and temperature dependence of the ammonium nitrate dissociation constant, Atmos. Environ., 16, 983-992, doi:10.1016/00046981(82)90184-6, 1982.

Stohl, A., Hittenberer, M., and Wotawa, G.: Validation of the Lagrangian particle dispersion model Flexpart against largescale tracer experiment data, Atmos. Environ., 32, 4245-4264, doi:10.1016/S1352-2310(98)00184-8, 1998.

Tao, J., Ho, K. F., Chen, L. G., Zhu, L. H., Han, J. L., and Xu, Z. C.: Effect of chemical composition of $\mathrm{PM}_{2.5}$ on visibility in Guangzhou, China, 2007 Spring, Particulogy, 7, 68-75, doi:10.1016/j.partic.2008.11.002, 2009.

Tsigaridis, K., Daskalakis, N., Kanakidou, M., Adams, P. J., Artaxo, P., Bahadur, R., Balkanski, Y., Bauer, S. E., Bellouin, N., Benedetti, A., Bergman, T., Berntsen, T. K., Beukes, J. P., Bian, H., Carslaw, K. S., Chin, M., Curci, G., Diehl, T., Easter, R. C., Ghan, S. J., Gong, S. L., Hodzic, A., Hoyle, C. R., Iversen, T., Jathar, S., Jimenez, J. L., Kaiser, J. W., Kirkevåg, A., Koch, D., Kokkola, H., Lee, Y. H., Lin, G., Liu, X., Luo, G., Ma, X., Mann, G. W., Mihalopoulos, N., Morcrette, J.-J., Müller, J.-F., Myhre, G., Myriokefalitakis, S., Ng, N. L., O’Donnell, D., Penner, J. E., Pozzoli, L., Pringle, K. J., Russell, L. M., Schulz, M., Sciare, J., Seland, Ø., Shindell, D. T., Sillman, S., Skeie, R. B., Spracklen, D., Stavrakou, T., Steenrod, S. D., Takemura, T., Tiitta, P., Tilmes, S., Tost, H., van Noije, T., van Zyl, P. G., von Salzen, K., Yu, F., Wang, Z., Wang, Z., Zaveri, R. A., Zhang, H., Zhang, K., Zhang, Q., and Zhang, X.: The AeroCom evaluation and intercomparison of organic aerosol in global models, Atmos. Chem. Phys., 14, 10845-10895, doi:10.5194/acp-1410845-2014, 2014.

Volkamer, R., Ziemann, P. J., and Molina, M. J.: Secondary Organic Aerosol Formation from Acetylene $\left(\mathrm{C}_{2} \mathrm{H}_{2}\right)$ : seed effect on SOA yields due to organic photochemistry in the aerosol aqueous phase, Atmos. Chem. Phys., 9, 1907-1928, doi:10.5194/acp9-1907-2009, 2009.

Wang, Y., Zhuang, G. S., Tang, A. H., Yuan, H., Sun, Y. L., Chen, S., and Zheng, A. H.: The ion chemistry and the source of $\mathrm{PM}_{2.5}$ aerosol in Beijing, Atmos. Enviorn., 39, 3771-3784, doi:10.1016/j.atmosenv.2005.03.013, 2005.

Wang, Z., Wang, T., Gao, R., Xue, L. K., Guo, J., Zhou, Y., Nie, W., Wang, X. F., Xu, P. J., Gao, J., Zhou, X. H., Wang, W. X., and Zhang, Q. Z.: Source and variation of carbonaceous aerosols at Mount Tai, North China: results from a semi-continuous instrument, Atmos. Environ., 45, 1655-1667, doi:10.1016/j.atmosenv.2011.01.006, 2011.

Wang, X. F., Wang, W. X., Yang, L. X., Gao, X. M., Nie, W., Yu, Y. C., Xu, P. J., Zhou, Y., and Wang, Z.: The secondary formation of inorganic aerosols in the droplet mode through heterogeneous aqueous reactions under haze conditions, Atmos. Environ., 63, 68-76, doi:10.1016/j.atmosenv.2012.09.029, 2012.

Yang, X. and Wenig, M.: Study of columnar aerosol size distribution in Hong Kong, Atmos. Chem. Phys., 9, 6175-6189, doi:10.5194/acp-9-6175-2009, 2009.

Yao, X. H., Lau, A. P. S., Fang, M., Chan, C. K., and Hu, M.: Size distributions and formation of ionic species in atmospheric particulate pollutants in Beijing, China: 2-dicarboxylic acids, Atmos. Environ., 37, 3001-3007, doi:10.1016/S13522310(03)00256-5, 2003a.

Yao, X. H., Fang, M., and Chan, C. K. The size dependence of chloride depletion in fine and coarse sea-salt particles, Atmos. Environ., 37, 742-751, doi:10.1016/S1352-2310(02)00955-X, 2003b.

Yao, X. H., Ling, T. Y., Fang, M., and Chan, C. K.: Comparison of thermodynamic predictions for in situ $\mathrm{pH}$ in $\mathrm{PM}_{2.5}$, Atmos. Environ., 40, 2835-2844, doi:10.1016/j.atmosenv.2006.01.006, 2006.

Yu, C., Chen, L. F., Li, S. S., Tao, J. H., and Su, L.: Estimating Biomass Burned Areas from Multispectral Dataset Detected by Multiple-Satellite, Spectrosc. Spect. Anal., 35, 739745, doi:10.3964/j.issn.1000-0593(2015)03-0739-07, 2015.

Zhang, Z. S., Engling, G., Chan, C. Y., Yang, Y. H., Lin, M., Shi, S., He, J., Li, Y. D., and Wang, X. M.: Determination of isoprene-derived secondary organic aerosol tracers (2-methyltetrols) by HPAEC-PAD: Results from size-resolved aerosols in a tropical rainforest, Atmos. Environ., 70, 468-476, doi:10.1016/j.atmosenv.2013.01.020, 2013a.

Zhang, Q., Tie, X. X., Lin, W. L., Cao, J. J., Quan, J. N., Ran, L., and $\mathrm{Xu}, \mathrm{W}$. Y.: Variability of $\mathrm{SO}_{2}$ in an intensive fog in North China Plain: Evidence of high solubility $\mathrm{SO}_{2}$, Particuology, 11, 41-47, doi:10.1016/j.partic.2012.09.005, 2013b.

Zhang, Z. S., Engling, G., Zhang, L. M., Kawamura, K., Yang, Y. H., Tao, J., Zhang, R. J., Chan, C. Y., and Li, Y. D.: Significant influence of fungi on coarse carbonaceous and potassium aerosols in a tropical rainforest, Environ. Res. Lett., 10, 034015 , doi:10.1088/1748-9326/10/3/034015, 2015.

Zhao, Y. L. and Gao, Y.: Mass size distributions of water-soluble inorganic and organic ions in size-segregated aerosols over metropolitan Newark in the US east coast, Atmos. Environ., 42, 4063-4078, doi:10.1016/j.atmosenv.2008.01.032, 2008a.

Zhao, Y. L. and Gao, Y.: Acidic species and chloride depletion in coarse aerosol particles in the US east coast, Sci. Total Environ., 407, 541-547, doi:10.1016/j.scitotenv.2008.09.002, 2008b.

Zheng, J. Y., Zhang, L. J., Che, W. W., Zheng, Z. Y., and Yin, S. S.: A highly resolved temporal and spatial air pollutant emission inventory for the Pearl River Delta region, China and its uncertainty assessment, Atmos. Environ., 43, 5112-5122, doi:10.1016/j.atmosenv.2009.04.060, 2009.

Zheng, J. Y., He, M., Shen, X. L., Yin, S. S., and Yuan, Z. B.: High resolution of black carbon and organic carbon emissions in the Pearl River Delta region, China, Sci. Total Environ.t, 438, 189200, doi:10.1016/j.scitotenv.2012.08.068, 2012.

Zhou, S. Z., Davy, P. K., Wang, X. M., Cohen, J. B., Liang, J. Q., Huang, M.J ., Fan, Q., Chen, W. H. Chang, M., Ancelet, T., and Trompetter, W. J.: High time-resolved elemental components in- 
fine and coarse particles in the Pearl River Delta region of Southern China: Dynamic variations and effects of meteorology, Sci. Total Environ., in press, doi:10.1016/j.scitotenv.2016.05.194, 2016.

Zhou, Y., Xue, L. K., Wang, T., Gao, X. M., Wang, Z., Wang, X. F., Zhang, J. M., Zhang, Q. Z., and Wang, W. X.: Characterization of aerosol acidity at a high mountain site in central eastern China, Atmos. Environ., 51, 11-20, doi:10.1016/j.atmosenv.2012.01.061, 2012.
Zhuang, H., Chan, C. K., Fang, M., and Wexler, A. S.: Size distributions of particulate sulfate, nitrate and ammonium at a suburban site in Hong Kong, Atmos. Environ.,33, 843-853, doi:10.1016/S1352-2310(98)00305-7, 1999. 